\title{
Antimicrobial resistance in the globalized food chain: a One Health perspective applied to the poultry industry
}

\author{
Mauro de Mesquita Souza Saraiva ${ }^{1,2} \cdot K_{\text {Kelvin } \text { Lim }^{3} \cdot \text { Daniel Farias Marinho do Monte }}^{2} \cdot$ \\ Patrícia Emília Naves Givisiez ${ }^{1}$. Lucas Bocchini Rodrigues Alves ${ }^{2}$. Oliveiro Caetano de Freitas Neto ${ }^{4}$. \\ Samuel Kariuki ${ }^{5,6}$. Angelo Berchieri Júnior ${ }^{2}$. Celso José Bruno de Oliveira ${ }^{1,6}$. Wondwossen Abebe Gebreyes ${ }^{6,7}$ (1)
}

Received: 9 April 2021 / Accepted: 21 October 2021 / Published online: 13 November 2021

(c) Sociedade Brasileira de Microbiologia 2021

\begin{abstract}
Antimicrobial resistance (AMR) remains a major global public health crisis. The food animal industry will face escalating challenges to increase productivity while minimizing AMR, since the global demand for animal protein has been continuously increasing and food animals play a key role in the global food supply, particularly broiler chickens. As chicken products are sources of low-cost, high-quality protein, poultry production is an important economic driver for livelihood and survival in developed and developing regions. The globalization of the food supply, markedly in the poultry industry, is aligned to the globalization of the whole modern society, with an unprecedented exchange of goods and services, and transit of human populations among regions and countries. Considering the increasing threat posed by AMR, human civilization is faced with a complex, multifaceted problem compromising its future. Actions to mitigate antimicrobial resistance are needed in all sectors of the society at the human, animal, and environmental levels. This review discusses the problems associated with antimicrobial resistance in the globalized food chain, using the poultry sector as a model. We cover critical aspects of the emergence and dissemination of antimicrobial resistance in the poultry industry and their implications to public health in a global perspective. Finally, we provide current insights using the multidisciplinary One Health approach to mitigate AMR at the human-animal-environment interface.
\end{abstract}

Keywords Aminoglycosides $\cdot \beta$-Lactams $\cdot$ Broilers $\cdot$ Fluoroquinolones $\cdot$ Gram-negative $\cdot$ Gram-positive $\cdot$ Tetracyclines

Celso José Bruno de Oliveira and Wondwossen Abebe Gebreyes contributed equally to this work.

Responsible Editor: Miliane Moreira Soares de Souza

Wondwossen Abebe Gebreyes

gebreyes.1@osu.edu

1 Department of Animal Science, Center for Agricultural Sciences, Federal University of Paraiba (CCA/UFPB), Areia, PB, Brazil

2 Department of Pathology, Theriogenology, and One Health, Sao Paulo State University (FCAV-Unesp), Jaboticabal, SP, Brazil

3 Veterinary Health Management Branch, National Parks Board, 6 Perahu Road, Singapore, Singapore

\section{Poultry industry and its role in the global food supply}

The consumption of animal protein is the basis of human food. Poultry meat production, which accounts for approximately one-third of the overall meat production worldwide [1,2], has increased rapidly over the last 50 years. The poultry industry will drive meat production growth

4 Department of Veterinary Sciences, School of Veterinary, Federal University of Minas Gerais (UFMG), Belo Horizonte, MG, Brazil

5 Kenya Medical Research Institute, Nairobi, Kenya

6 Global One Health initiative (GOHi), The Ohio State University, Columbus, OH, USA

7 Department of Veterinary Preventive Medicine, The Ohio State University, Columbus, OH 43210, USA 
in the coming decade, and it is projected to account for half of all additional meat produced in that time period [3]. Poultry meat output was forecasted to expand and reach 137 million tonnes in 2020 , a $2.6 \%$ rise compared to 2019 , despite the dampened food services sales during the COVID-19 pandemic, intentional production curbs, and avian influenza outbreaks [4]. The USA, Brazil, the European Union, and China continue to be the leading producers of poultry meat globally [3]. Out of the total meat trade globally (37.6 million tonnes), 14.1 million tonnes $(37.5 \%)$ relate to poultry meat exported by leading producing countries, making chicken the most exported type of meat. This highlights the great economic importance of the poultry industry as a global commodity, leveraging worldwide economic activities in the industrial, commercial, and service sectors.

The relative affordability is an important driver for the increasing consumer willingness to replace beef and pork by poultry meat. Advantageous economies of scale and cost-efficiencies lead to cascading effects through poultry value chains from production to foreign trade [3]. Therefore, the industrial poultry production has a tradition to be in the vanguard in terms of technological advances in the areas of nutrition, breeding, management, and health.

Moreover, the increasing demand for poultry meat is related to the growing demand for meat protein globally as the human population is expected to reach 9.7 billion in 2050 and 10.9 billion in 2100 [5]. Human population in less developed countries will at least double by 2050 , whereas much lower growth rates will occur in developed areas [5]. For example, there is a dramatic increase $(725 \%)$ in the projected demand for poultry meat in South Asia by 2030, especially in countries such as India, where poultry meat consumption is estimated to grow from 1.05 to 9.92 million tonnes annually over the next three decades [6].

Given the increasing demand for poultry meat in highly populated urban areas, the poultry industry will move towards more intensified trade activities over the next decades. Technological development in the poultry industry will consolidate as a key driver for the success of the business and for reaching the society needs. These technologies must also improve the capacity of the industry to proper handle the increasing amount of animal waste, such as poultry litter, as it can be a vehicle for the spread of antibiotics, biocides, metabolites, pathogens, and antimicrobial resistance genes (ARG) in the environment [7]. The contamination of soil and water sources, such as rivers and ground- and coastal water, can have a profound and direct impact on the environmental resistome, especially in countries under poor sanitation conditions [7, 8]. In this scope, the technological development of the poultry industry should be embedded in Environmental, Social, and Governance (ESG) integrated initiatives for increasing performance and sustainability.

\section{The concept of antimicrobial resistance and its burden to public health}

Antimicrobial resistance is a natural, ancient, and common phenomenon in bacteria inhabiting any biological system [9]. However, some factors can favor the emergence and spread of antimicrobial resistance among bacteria. Anthropogenic factors seem to play an important role in this aspect, such as the overuse and misuse of antimicrobial agents, which generates selection pressure favoring the multiplication of antimicrobial-resistant organisms [10]. Antimicrobial agents can eliminate or inhibit the growth of susceptible bacteria, allowing resistant strains to colonize and multiply in a given environment. Several experimental, epidemiological, and ecological studies have confirmed this hypothesis [11]. Therefore, antimicrobialresistant pathogens have the potential to cause hard-totreat diseases, increased mortality rates, and economic burden. Infections caused by antimicrobial-resistant pathogens are considered major global public health crisis by the World Health Organization as the discovery of effective antimicrobial drugs does not keep pace with the increasing antimicrobial resistance rates in bacteria.

The World Bank estimated that the loss of the annual global gross domestic product (GDP) by 2050 would fall $1.1 \%$ in the best case scenario of low AMR impact to 3.8\% in the worst case scenario, which translates to an annual shortfall of $\$ 3.4$ trillion by 2030 [12]. The O'Neill report on Review on Antimicrobial Resistance estimated the burden to be 10 million lives per year and cumulative 100 trillion USD of economic output by 2050 [13]. An estimation of global infections caused by drug-resistant WHO priority pathogens placed third-generation cephalosporinresistant Escherichia coli and Klebsiella pneumoniae to be responsible for approximately 4.6 to 6.4 million bloodstream infections in 2014 and carbapenem-resistant ones for approximately 0.4 to 0.5 million bloodstream infections [14].

\section{Important considerations on antimicrobials used in the poultry industry}

In quantitative terms, the amount of antimicrobial drugs used in livestock globally was estimated in 63,151 tonnes in 2010 , and it is expected to increase $67 \%$ by 2030 , reaching approximately 105,500 tonnes [15] following the rising demand for livestock products by the human population in middle-income countries. The amount of antimicrobials used in livestock is estimated to nearly double in countries such as the BRICS countries (Brazil, Russia, 
India, China, and South Africa). In spite of all efforts and competence of researchers working in this field, accurate numbers on the amount of antimicrobials used in food animals are extremely difficult to be reached because of lack of information and complexity of available data. There are important initiatives addressing data acquisition and availability, especially those led by the World Organization for Animal Health (OIE) database that serves as a global reference to national systems for monitoring the use of antimicrobials in animals. Nevertheless, these initiatives are at an early stage of development and face innumerous challenges related to the inaccessibly of data or calculation errors from many countries that are unable to provide reasonable accurate information [16]. Therefore, current calculations in terms of the amount of antimicrobials used in animals seem to be underestimated.

According to the 2016 OIE report [16], data collected from 93 countries globally indicated that Americas, Asia, and East Oceania used 87.13\% from 97,784 tonnes of antimicrobial agents intended for animal use that year, even though only 18 countries were able to distinguish which drugs were used in terrestrial food animals. Tetracyclines (33.8\%) and penicillins (20.4\%) were identified as the most frequently used drugs in these animals. According to this same report, increased estimates of antimicrobial use were observed after adjustments by animal biomass, as shown in Table 1 [16].

Antimicrobial drugs have played an important role in intensive animal production systems, and a wide variety of antimicrobials can be used in poultry production [17, 18]. Antimicrobial therapy of diseased animals is not only the most promising alternative to overcome the economic burden caused by bacterial infectious diseases in livestock, but also represents a welfare principle that must be used to avoid suffering of any food animal. Therefore, the

Table 1 Amounts of antimicrobial drugs used in food animals by animal biomass before and after adjustments, by country estimates of data coverage. Table was adapted from OIE report of the year 2020 [16].

\begin{tabular}{llll}
\hline OIE region & Countries* & \multicolumn{2}{l}{$\begin{array}{l}\text { Antimicrobial amounts used } \\
\text { by animal biomass }\end{array}$} \\
\cline { 3 - 4 } & & $\begin{array}{l}\text { Not adjusted } \\
(\mathrm{mg} / \mathrm{kg})\end{array}$ & $\begin{array}{l}\text { After adjust- } \\
\text { ment }(\mathrm{mg} / \\
\mathrm{kg})\end{array}$ \\
\hline Africa & 21 & 39.17 & 45.25 \\
$\begin{array}{l}\text { Americas } \\
\begin{array}{l}\text { Asia, Far East, and } \\
\text { Oceania }\end{array}\end{array}$ & 11 & 114.54 & 138.07 \\
Europe & 40 & 237.72 & 240.57 \\
\hline
\end{tabular}

*Number of countries providing data for food animals in all rounds of data collection for 2016, from 4 OIE regions success of poultry farming and other animal production systems will continue to depend on the existence of effective antimicrobials.

Besides therapy, antimicrobial drugs have been also used in poultry production for other purposes, such as metaphylaxis, i.e., the prophylactic treatment of the entire flock including animals that show no clinical sign of the disease in order to prevent the spread of a given disease, or as growth promoters, which are antimicrobials added to animal feed at low dosages to enhance animal performance. Although the use of antimicrobial drugs represents a driver for antimicrobial resistance in bacterial populations of every microenvironment using increased selective pressure, this phenomenon is significantly increased when antimicrobials are misused. Therefore, how antimicrobials are used in the food animal industry in terms of antimicrobial classes, the doses, and the purpose could have a great impact on the emergence and dissemination of antimicrobial resistance. While specific approved antimicrobials in veterinary medicine have been used therapeutically following veterinary recommendations, misuse of antimicrobials in food animals has been reported, such as the indiscriminate use of unprescribed drugs added to animal feed [19] or even added to vaccines [20] aiming to prevent disease and to improve animal performance. Thus, the use of antimicrobials in food animals should be also assessed in a qualitative perspective, given the fact that the non-therapeutic administration of antimicrobial drugs to livestock at sub-inhibitory dosages are supposed to have a greater impact on the emergence and dissemination of antimicrobial resistance. The problem is critical when these drugs relate to antimicrobial classes that are considered critically important to human health [21], which makes the non-therapeutic use of these drugs a global health concern. There are indications that antimicrobials in animal food production are directly related to the increase of antimicrobial resistance [22-25].

Importantly, there is a lack of new active principles or candidate interventions capable of overcoming resistance mechanisms developed by bacteria. Therefore, the rational use of these drugs seems the most adequate alternative to guarantee the effectiveness of already existing antimicrobials for treatment of diseases in animals and humans.

As also occurring in other sectors, certain animal production practices might contribute to the spread of antimicrobial-resistant bacteria. These practices include overprescription of broad-spectrum antimicrobials to animals [26], feeding of certain antibiotics at low doses for growth promotion purposes $[27,28]$, and the use of non-approved or off-label use of drugs [29].

However, this drug overuse might be deposited as antibiotic residues in foodstuffs such as meat, eggs, and milk, to name a few [30-33]. Several side effects have been related to antibiotic residues in foodstuffs, such as toxicity (bone 
marrow and hepatotoxicity), nephropathy, immunopathological effects (allergy), mutagenicity, and, especially, transfer of antibiotic resistance between MDR and commensal bacteria that may contribute to the imbalance of gut microbiota posing hazards to human health [30-33].

To address this concern effectively, some actions delivered by all sectors are needed to avoid the spread of these antimicrobial residues in foodstuffs. First, farmers must have the drug withdrawal period as a priority to safeguard human health. Second, the poultry industries must establish measurement strategies to detect antimicrobials in poultry products and related sources, including quantitative (liquid chromatography, capillary electrophoresis, enzyme linked immunosorbent assay), semi-quantitative (microbiology assay), and qualitative (x-ray diffraction) techniques [33]. Lastly, food authorities must be aware and monitor the previous steps made by the whole food chain sector.

\section{Emergence and spread of antimicrobial resistance in the poultry production: a two-faceted problem}

As in other sectors, the use of drugs in poultry production eliminates susceptible bacteria favoring the selection of resistant isolates. These persistent isolates become predominant and can transfer their resistance genes to both clonal descendants and also to other isolates from the same bacterial species or even from other species [34]. In this context, the problem of antimicrobial resistance in poultry production needs to be understood from two different perspectives: (i) the emergence and dissemination of antimicrobial-resistant zoonotic pathogens that represent a direct hazard in public health and (ii) the emergence and dissemination of commensal bacteria carrying ARGs in mobile genetic elements that can be further contributed as source of important resistance genes potentially transferred to pathogenic bacteria within a given host or in the environment $[7,8]$. This explains the high complexity of antimicrobial resistance in the poultry industry, as illustrated in Fig. 1.

Another critical issue in the acquisition of resistance mechanisms is the identification of transmission routes of resistant bacteria along the food chain. Although it remains difficult to identify when the contamination begins, several insights can be denoted in One Health framework, including risk factors associated with the farm environment, food industry, and household settings as summarized in Fig. 1. Among these factors, transmission via vectors, water, soil, plants, animal feed, poultry, and anthropological actions play a crucial role to the development and spread of antimicrobial resistance in a global scale [36].

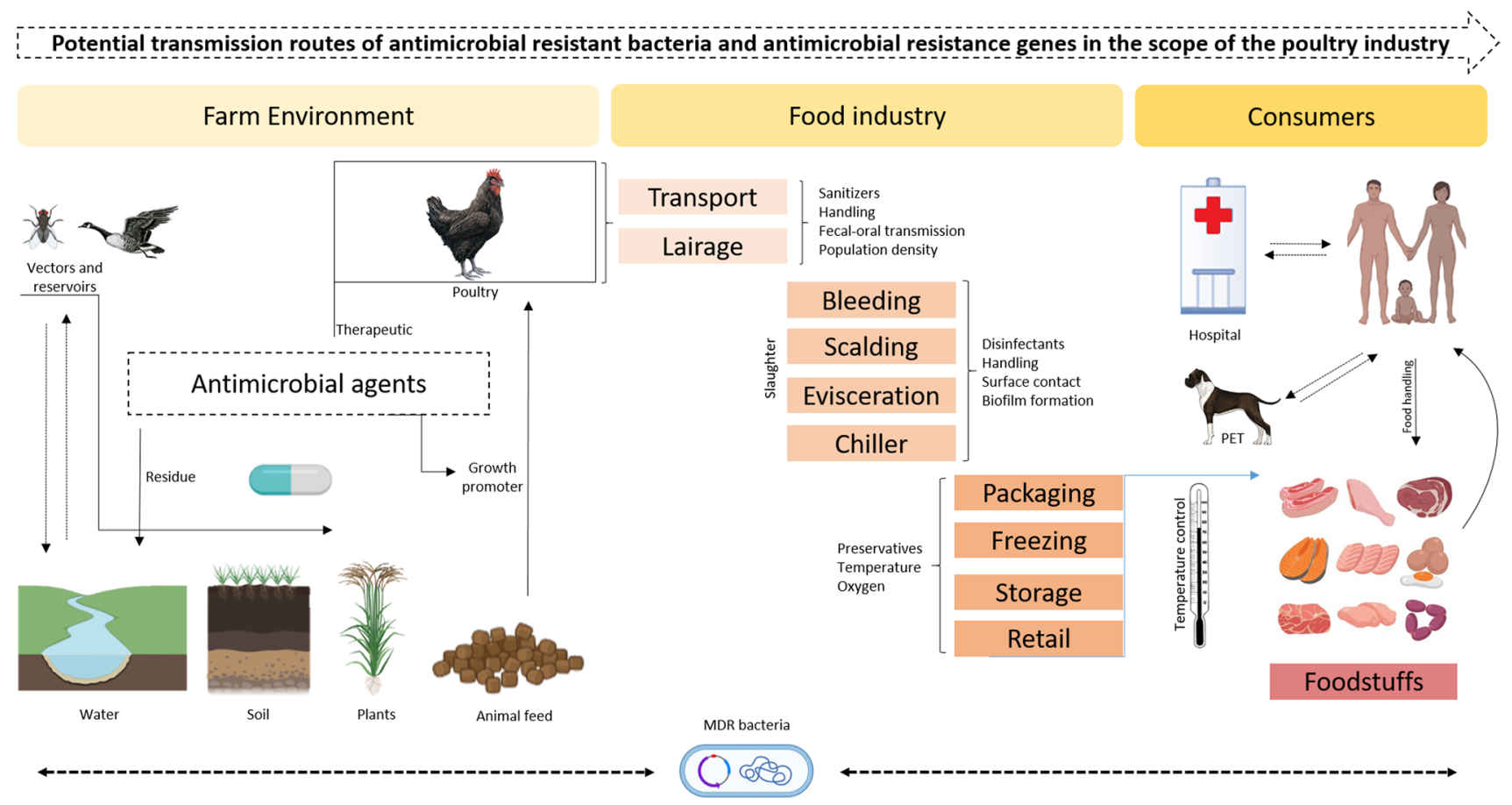

Fig. 1 Potential transmission routes of antimicrobial-resistant bacteria and antimicrobial resistance genes in the scope of the poultry industry (adapted from Monte et al. [35]). This figure was created using BioRender.com. 


\section{Antimicrobial resistance in zoonotic pathogens associated with poultry products}

A wide variety of antimicrobial-resistant bacteria of public health significance has been detected in broilers and laying hens. In this topic, we describe antimicrobial resistance levels among the most relevant zoonotic pathogens associated with chickens and poultry products: Salmonella spp. [37-39], Campylobacter spp. [37, 40, 41], Enterococcus spp. [42-44], Escherichia coli [43, 45], and Staphylococcus aureus $[42,46]$.

\section{Salmonella spp.}

Salmonellosis affects hundreds of people around the world, causing high fever and diarrhea that can progress to death [47]. Because of its global importance, many countries have implemented surveillance programs for Salmonella in livestock, allowing the acquisition of important information about antimicrobial resistance. More than 2,650 serovars of Salmonella enterica have been already identified [48], and several are found in foods such as chicken meat and eggs, considered key sources of infection and concern for public health [49-51]. In chickens, resistant Salmonella spp. not only can cause economic losses, but they can potentially cause occupational salmonellosis in farmers and keepers [52-54].

Salmonella diseases in birds can be divided into three distinct conditions: fowl typhoid, caused by Salmonella Gallinarum biovar Gallinarum (SG); pullorum disease, caused by Salmonella Gallinarum biovar Pullorum (SP); and avian paratyphoid, resulting from infection by any other serovar except those previously mentioned [55]. SG and SP only affect chickens and cause severe clinical signs and mortality, while SG affects birds of any age, and SP-associated infections occur in young birds. Chickens of light lineages are more resistant to fowl disease compared to semi-heavy and heavy lineages [56]. In contrast, paratyphoid Salmonella infections do not lead to clinical signs, but there are exceptions that can cause disease and mortality in chicks [55].

The epidemiology of salmonellosis is complex. The high density in the poultry houses along with the persistence of the microorganism in water, feed ingredients, litter, and fomites as well as in biological vectors on the farm environment facilitate its dissemination [57]. Transmission occurs through horizontal and vertical routes in the case of pullorum disease and avian paratyphoid $[55,58]$, and only by horizontal route in fowl typhoid [59].

A previous study on semi-heavy laying hens showed that treatment with antimicrobials was able to reduce mortality caused by fowl typhoid only temporarily; death and compromised egg production were observed after treatment was suspended [59]. Thus, the efficacy of antimicrobials in controlling disease is limited and can promote the emergence of resistant Salmonella strains [55, 59]. In the case of paratyphoid Salmonella, multi-resistance is of concern as it promotes failures in the treatment of infection in humans who have ingested chicken meat or eggs contaminated by zoonotic serotypes such as $S$. Enteritidis, $S$. Typhimurium, $S$. Heidelberg, $S$. Hadar, $S$. Infantis, $S$. Mbandaka, $S$. Saintpaul, and $S$. Newport, among others [60-62]. A high and diverse level of antimicrobial resistance was identified in approximately 4,000 isolates from 14 different studies (Table 2). Nalidixic acid (95.2\%), amoxicillin (91.6\%), ampicillin (100\%), erythromycin $(100 \%)$, penicillin G $(100 \%)$, sulfamethoxazole $(100 \%)$, and tetracycline $(93 \%)$ showed the highest resistances, while higher sensitivities were obtained for aminoglycosides (spectinomycin - 96\% and gentamicin - 99.8\%).

The emergence and spread of antimicrobial-resistant, in particular multidrug-resistant Salmonella strains (MDR strains), is a major public health concern [63]. While Salmonella continues to be a major cause of foodborne disease in most countries, the reduced number of antimicrobials available for therapeutic purposes in humans and animals exacerbates the issue [64]. The proportion of Salmonella isolates resistant to ceftriaxone and ciprofloxacin in the USA has increased year on year [65]. MDR Salmonella recovered from chicken samples during veterinary inspection service in the USA has increased, remarkably for Salmonella Infantis [65]. Nontyphoidal MDR Salmonella is estimated to be responsible for 20,800 infections per year in the USA [66]. The most common antimicrobial resistance patterns of multidrug-resistant Salmonella strains related to important therapeutic antimicrobial classes are used in humans, including penicillins, tetracyclines, cephalosporins, and fluoroquinolones [28].

The frequency and extent of resistance in Salmonella varies according to the antimicrobial use and the ecological differences in its epidemiology [67]. Some multidrugresistant Salmonella strains with extensive resistance profiles pose greater threats to public health and have been associated with higher mortality and morbidity rates [41]. Multidrug resistance in Salmonella spp. to ampicillin, chloramphenicol, streptomycin, sulfonamides, and tetracycline (ACSSuT) has been associated with invasive disease in humans [64]. Another multidrug-resistant pattern with additional resistance to amoxicillin-clavulanic acid and ceftriaxone (ACSSuTAuCx) had been associated with severe disease in humans [68], while the monophasic ST35 variant is associated to colistin resistance [69]. 
Table 2 Summary of antimicrobial resistance results in Salmonella spp. isolated from poultry published in the last 5 years, within the five continents.

\begin{tabular}{|c|c|c|c|c|c|}
\hline Study & Region & Reference & Publishing year & No. of isolates & Resistance profile $(\%)$ \\
\hline 1 & Africa & Abd-Elghany et al. & 2015 & 166 & $\begin{array}{l}\text { AMP }(74,7), \text { AMX }(91,6), \text { C }(47), \text { CIP }(19,3), \text { ERY }(100), \\
\text { GM }(1,2), \text { KA }(9,6), \text { NAL }(95,2), \text { NEO }(61,4), \text { NOR } \\
(30,1), \text { OT }(89,2), \text { P }(92,8), \text { S }(67,5), \text { SUL }(83,1)\end{array}$ \\
\hline 2 & Africa & Zishiri et al. & 2016 & 102 & $\begin{array}{l}\operatorname{AMP}(47), \operatorname{AMX}(31), \mathrm{C}(31), \mathrm{ERY}(18), \mathrm{GM}(48), \mathrm{KA} \\
\text { (74), S (12), SXT }(84,3), \mathrm{T}(93), \mathrm{TMP}(78,4)\end{array}$ \\
\hline 3 & Africa & Eguale & 2018 & 26 & $\begin{array}{l}\text { AMC }(42,3), \operatorname{AMP}(42,3), \mathrm{C}(42,3), \operatorname{CFN}(46,2, \mathrm{CIP}(7,7), \\
\text { FOX }(0), \mathrm{GM}(7,7), \operatorname{KA}(42,3), \operatorname{NAL}(19), \mathrm{NEO}(11,5), \\
\text { NIT }(26,7), \mathrm{S}(92,3), \operatorname{SUL}(92,3), \operatorname{SXT}(3,9), \mathrm{T}(30,8), \\
\text { TMP }(3,9)\end{array}$ \\
\hline 4 & North America & Ladely et al. & 2016 & S. Kentucky 600 & $\begin{array}{l}\text { AK (0), AMC (15,3), AMP }(16,7), \text { C (2), CEF }(14,8), \text { CIP } \\
(0), \text { CRO }(15,2), \text { FOX }(14,3), \text { GM }(2), \operatorname{KA}(1,3), \text { NAL } \\
(0,3), \text { S }(46,5), \text { SUL }(3,5), \text { SXT }(0,2), \text { T }(50)\end{array}$ \\
\hline 5 & North America & Nisar et al. & 2017 & 19 & $\begin{array}{l}\text { AMC }(15,8), \operatorname{AMP}(10,5), \text { AZI }(0), \text { C }(5,2), \text { CEF }(5,2), \\
\text { CIP (0), FOX }(10,5), \text { GM }(10,5), \text { NAL }(0), \text { S }(21,1), \text { SUL } \\
(21,1), \operatorname{SXT}(0), \text { T }(21,1)\end{array}$ \\
\hline 6 & South America & Donado-Godoy et al. & 2014 & 39 & AMP (82), CEF (74), CIP (69), CTX (69) \\
\hline 7 & South America & Vinueza-Burgos et al. & 2016 & 62 & $\begin{array}{l}\text { AMP }(67,7), \mathrm{C}(64,5), \operatorname{CAZ}(6,5), \operatorname{CIP}(83,9), \operatorname{COL}(16,1), \\
\text { CTX (71), FFC }(67,7), \text { GM }(66,1), \operatorname{KA}(51,6), \text { NAL }(85,5), \\
\text { S }(79), \operatorname{SUL}(88,7), \mathrm{T}(80,6), \text { TMP }(80,6)\end{array}$ \\
\hline 2 & South America & Zishiri et al. & 2016 & 24 & $\begin{array}{l}\text { AMP }(100), \text { AMX }(83), \text { C }(4,2), \text { ERY }(62,5), \text { GM }(12,5), \\
\text { KA }(16,7), \text { S }(12,5), \text { SXT }(50), \text { T }(83), \text { TMP }(66,7)\end{array}$ \\
\hline 8 & South America & Cunha-Neto et al. & 2018 & 31 & $\begin{array}{l}\text { AMP (25), AZI }(21,8), \mathrm{C}(3,1), \mathrm{CEF}(6,3), \mathrm{CFN}(25), \mathrm{CIP} \\
\text { (0), ENR (0), FFC (0), FOX }(18,8), \mathrm{GM}(3,1), \mathrm{NAL}(0), \\
\text { NIT (0), S (0), SUL (100), SXT }(75), \mathrm{T}(9,4), \text { TMP }(87,5)\end{array}$ \\
\hline 9 & Asia & Thung et al. & 2016 & 11 & $\begin{array}{l}\text { AMC (0), AMP (72,7), AMX }(27,3), \operatorname{CAZ}(0), \operatorname{CFZ}(27,3), \\
\text { CIP }(27,3), \text { ERY }(100), \text { GM }(0), \operatorname{KA}(0), \operatorname{NAL}(9,1), \text { P } \\
(100), S(9,1), \text { T }(0), \text { TMP }(0), \operatorname{VAN}(100)\end{array}$ \\
\hline 10 & Asia & Trongjit et al. & 2017 & 375 & $\begin{array}{l}\text { AMP }(70,7), \mathrm{C}(10,7), \mathrm{CAZ}(4,3), \mathrm{CIP}(0,6), \mathrm{CPD}(4,9), \\
\text { CTX }(3,8), \mathrm{GM}(2,9), \mathrm{S}(28), \operatorname{SUL}(69,5), \mathrm{T}(26), \mathrm{TMP} \\
(29,6)\end{array}$ \\
\hline 11 & Asia & Uddin et al. & 2018 & 150 & $\begin{array}{l}\text { AMC (30), AMP (75), AZI (70), BAC (56), C (41), CE (0), } \\
\text { CIP (4), CRO (0), ERY (40), FEP (0), KA (8), NAL (50), } \\
\text { NEO (80), NV (74), S (31), SPT (4), T (89), TZP (0) }\end{array}$ \\
\hline 12 & Europe & de Jong et al. & 2014 & 42 & $\begin{array}{r}\operatorname{AMC}(2,9), \operatorname{AMP}(35,4), \mathrm{C}(3,3), \mathrm{CIP}(0), \operatorname{COL}(10,4), \mathrm{CTX} \\
(13,1), \mathrm{GM}(0,2), \text { NAL }(22,8), \mathrm{S}(24,3), \mathrm{SXT}(26,8), \mathrm{T}(15)\end{array}$ \\
\hline 13 & Europe & Franco et al. & 2015 & 42 & $\begin{array}{l}\text { AMP }(78,6), \text { C }(4,8), \text { CIP }(83,3), \text { CTX }(71,4), \text { GM }(2,4), \text { KA } \\
(40,5), \text { NAL }(83,3), \text { S }(19), \text { SUL }(85,7), \text { T }(85,7), \text { TMP } \\
(83,3)\end{array}$ \\
\hline 14 & Europe & EFSA & 2016 & 2210 & $\begin{array}{l}\text { AMP }(19,1), \text { AZI }(1,9), \text { C }(4), \text { CAZ }(2,6), \operatorname{CIP}(53,5), \text { COL } \\
(8,3), \text { CTX }(2,3), \text { GM }(6,6), \text { NAL }(48,7), \text { SUL }(45,1), \text { T } \\
(40,4), \text { TGC }(9,3), \text { TMP }(16,9)\end{array}$ \\
\hline
\end{tabular}

$A K$ amikacin, $A M C$ amoxicillin/clavulanic acid, $A M P$ ampicillin, $A M X$ amoxicillin, $A Z I$ azithromycin, $B A C$ bacitracin, $C$ chloramphenicol, $C A Z$ ceftazidime, $C E$ cefradine, $C E F$ ceftiofur, $C F N$ cephalothin, $C F Z$ cefazoline, $C I P$ ciprofloxacin, $C L X$ cefalexin, $C O L$ colistin, $C P D$ cefpodoxime, $C R O$ ceftriaxone, $C T X$ cefotaxime, $E N R$ enrofloxacin, $E R Y$ erythromycin, $F E P$ cefepime, $F F C$ florfenicol, $F O X$ cefoxitin, $G M$ gentamicin, $K A$ kanamycin, $N A L$ nalidixic acid, $N E O$ neomycin, $N I T$ nitrofurantoin, $N O R$ norfloxacin, $N V$ novobiocin, $O T$ oxytetracycline, $P$ penicillin, $S$ streptomycin, $S P$ spermidine, $S P T$ spectinomycin, $S U L$ sulfamethoxazole, $S X T$ sulfamethoxazole/trimethoprim, $T$ tetracycline, $T G C$ tigecycline, $T M P$ trimethoprim, TZP piperacillin/tazobactam, VAN vancomycin

\section{Campylobacter spp.}

Campylobacter species can cause disease in animals and humans [70] and are a major cause of foodborne diseases worldwide. Both Campylobacter jejuni ( $C$. jejuni) and $C$. coli can colonize the gut of broilers. Human infections, of particular concern when involving children [71], are usually caused by consumption of contaminated poultry products, even though occupational transmission has been observed.

Due to the high occurrence of Campylobacter spp. in the environment, including soil and water, and the high diversity of susceptible vector hosts $[72,73]$,, the epidemiology is 
very complex. Wild animals and pests, as well as humans and vehicles, can introduce Campylobacter spp. onto the farm [38]. Even though the real role of the feed as source of Campylobacter is unclear [41], the bacteria can survive and multiply in foods under different storage temperatures [74]. High morbidity can be observed in domestic birds, and transmission occurs through both horizontal and vertical routes $[41,72,75]$.

When infecting the bird, Campylobacter spp. effectively colonizes the intestine, mainly the mucosa of the cecal crypts. It can invade the intestinal epithelium and multiply rapidly in the intestinal mucus to avoid clearance [74]. In addition, it is able to persist under commensal conditions due to the weak immune response of the animal, making the bird a reservoir of human campylobacteriosis [41, 72].
Antimicrobial therapy, besides being ineffective in eliminating Campylobacter due to its high occurrence and commensal relationship in birds [41], can promote the emergence of resistant strains. Therefore, biosecurity practices are the most appropriate way to reduce the infection at the flock level [72]. Other approaches such as the use of organic acids to reduce the $\mathrm{pH}$ of the gastrointestinal tract and competitive exclusion can reduce intestinal colonization by the microorganism $[41,75]$.

In nine recent studies, antimicrobial resistance profiles of more than 2,000 isolates of Campylobacter spp. were evaluated in broilers [76-79], laying hens [77], chicken carcasses [77, 80-82], and chicken meat or offal [81, 83, 84]. High frequencies of resistance to nalidixic acid (100-38.5\%), ampicillin (100-8.8\%), cephalexin (100-85.7\%), ciprofloxacin

Table 3 Summary of antimicrobial resistance results in Campylobacter spp. isolated from poultry published in the last 5 years, within the five continents.

\begin{tabular}{|c|c|c|c|c|c|}
\hline Study & Region & Reference & Publishing year & No. of isolates & Resistance profile (\%) \\
\hline \multirow[t]{3}{*}{1} & \multirow[t]{3}{*}{ Africa } & \multirow[t]{3}{*}{ Karikari et al. } & \multirow[t]{3}{*}{2017} & C. jejuni 39 & $\begin{array}{l}\text { AMP }(100), \text { C }(84,6), \text { CIP }(69,2), \operatorname{CLX}(100), \text { CTX }(87,2), \\
\text { ERY }(100), \text { GM }(23,1), \text { KA }(28,2), \text { NAL }(38,5), \text { NOR }(48,7) \\
\text { SXT }(92,3), \text { T }(100)\end{array}$ \\
\hline & & & & C. coli 14 & $\begin{array}{l}\text { AMP }(100), \text { C }(64,3), \text { CIP }(64,3), \text { CLX }(85,7), \text { CTX }(85,7), \\
\text { ERY }(100), \text { GM }(0), \text { KA }(28,6), \text { NAL }(7,4), \text { NOR }(0), \text { SXT } \\
(92,9), \text { T }(92,9)\end{array}$ \\
\hline & & & & C. iari 9 & $\begin{array}{l}\text { AMP (100), C (55,6), CIP (100), CLX }(100) \text {, CTX }(100) \text {, ERY } \\
(100), \text { GM }(33,3) \text {, KA }(33,3) \text {, NAL }(100) \text {, NOR }(77,8) \text {, SXT } \\
(88,9), \text { T }(100)\end{array}$ \\
\hline \multirow[t]{2}{*}{2} & \multirow[t]{2}{*}{ North America } & \multirow[t]{2}{*}{ Kassem et al. } & \multirow[t]{2}{*}{2017} & C. jejuni 45 & CIP $(15,6)$, ERY $(20), S(11,1)$, T $(64,4)$, TYL $(33,3)$ \\
\hline & & & & C. coli 155 & CIP $(7,1)$, ERY $(26,5), S(10,3)$, T $(66,5)$, TYL $(28,4)$ \\
\hline 3 & South America & Donado-Godoy et al. & 2014 & 29 & CIP (97), ERY (21), T (83) \\
\hline \multirow[t]{2}{*}{4} & \multirow[t]{2}{*}{ South America } & \multirow[t]{2}{*}{ Panzenhagen et al. } & \multirow[t]{2}{*}{2016} & C. jejuni 44 & CIP (100), ENR (100) \\
\hline & & & & C. coli 38 & CIP (100), ENR (100) \\
\hline \multirow[t]{2}{*}{5} & \multirow[t]{2}{*}{ South America } & \multirow[t]{2}{*}{ Vinueza-Burgos et al. } & \multirow[t]{2}{*}{2017} & C. jejuni 48 & CIP $(97,9)$, ERY $(4,2)$, GM $(2,1)$, NAL $(100), S(8,4), T(83,4)$ \\
\hline & & & & C. coli 170 & $\begin{array}{l}\text { CIP (100), ERY }(25,8), \text { GM }(1,2), \text { NAL }(99,3), S(11,2), T \\
\quad(67,6)\end{array}$ \\
\hline \multirow[t]{2}{*}{6} & \multirow[t]{2}{*}{ Asia } & \multirow[t]{2}{*}{ Han et al. } & \multirow[t]{2}{*}{2016} & C. jejuni 160 & $\begin{array}{l}\text { CIP }(88,1), \text { CLD }(68,1), \text { ERY }(14,3), \text { FFN }(16,3), \text { GM }(47,5) \text {, } \\
\text { LEV }(78,1), S(43,8) \text {, T }(79,4)\end{array}$ \\
\hline & & & & C. coli 130 & $\begin{array}{l}\text { CIP (100), CLD }(98,5), \text { ERY }(93,5), \text { FFN }(8,5), \text { GM }(90,8), \\
\text { LEV }(98,5), \text { S }(17,8), T(98,5)\end{array}$ \\
\hline \multirow[t]{2}{*}{7} & \multirow[t]{2}{*}{ Asia } & \multirow[t]{2}{*}{ Kottawatta et al. } & \multirow[t]{2}{*}{2017} & C. jejuni 20 & $\begin{array}{l}\text { AMP (45), C (0), CIP (80), CLA (0), ERY (5), GM (10), NAL } \\
\text { (80), NEO (10), S (5), SUL (0), T (85), TUL (5) }\end{array}$ \\
\hline & & & & C. coli 45 & $\begin{array}{l}\text { AMP }(8,8), C(2,2), \text { CIP }(84,4), \text { CLA }(6,6), \text { ERY }(11,1), \text { GM } \\
(2,2), \text { NAL }(84,4), \text { NEO }(8,8), \text { S }(4,4), \text { SUL }(2,2), T(24,4), \\
\text { TUL }(6,6)\end{array}$ \\
\hline \multirow[t]{2}{*}{8} & \multirow[t]{2}{*}{ Europe } & \multirow[t]{2}{*}{ Wieczorek e Osek } & \multirow[t]{2}{*}{2015} & C. jejuni 576 & CIP $(74,8)$, ERY $(0,9), T(46,5)$ \\
\hline & & & & C. coli 575 & CIP $(88,3)$, ERY $(4), T(65,7)$ \\
\hline \multirow[t]{3}{*}{9} & \multirow[t]{3}{*}{ Europe } & \multirow[t]{3}{*}{ García-Sánchez et al. } & \multirow[t]{3}{*}{2018} & C. jejuni 55 & $\begin{array}{l}\text { AZI (96), CIP (100), ERY (100), GM (100), NAL (100), T } \\
\text { (98) }\end{array}$ \\
\hline & & & & C. coli 19 & AZI (63), CIP (79), ERY (63), GM (95), NAL (100), T (100) \\
\hline & & & & C. lari 2 & AZI (0), CIP (100), ERY (0), GM (50), NAL (100), T (100) \\
\hline
\end{tabular}

$A M P$ ampicillin, $A Z I$ azithromycin, $C$ chloramphenicol, $C I P$ ciprofloxacin, $C L A$ clarithromycin, $C L D$ clindamycin, $C L X$ cefalexin, $C T X$ cefotaxime, $E N R$ enrofloxacin, $E R Y$ erythromycin, $F F N$ florfenicol, $G M$ gentamicin, $K A$ kanamycin, $L E V$ levofloxacin, $N A L$ nalidixic acid, $N E O$ neomycin, NOR norfloxacin, $S$ streptomycin, $S U L$ sulfamethoxazole, $S X T$ sulfamethoxazole/trimethoprim, $T$ tetracycline, $T U L$ tulathromycin 
(100-7.1), erythromycin (100-0.9\%), gentamicin (100-0\%), and tetracycline (100-24.4\%) were detected (Table 3 ).

\section{Enterococcus spp.}

Enterococcus species are part of the natural gut microbiota of both humans and animals and frequently contaminate the environment and foods, including chicken meat [85]. Although some strains have been used in probiotics, others have been reported as pathogenic strains for chickens [86]. In this case, there might be mortality without clinical signs during the acute phase, ranging from 1 to 3 weeks after infection [86]. In the case of clinical manifestation, septicemia is the most common observed condition. In general, transmission occurs via both horizontal and vertical routes. Among the pathogenic specimens for domestic birds, E. cecorum and E. faecalis can be highlighted [86].

E. cecorum has grown in importance from the past two decades after the epidemic of pathogenic strains in broilers, causing the so-called free thoracic vertebra (FTV) osteomyelitis [87]. The infection causes abscesses in the thoracic vertebrae that compress the spinal cord, leading the bird to remain supported under the tibiotarso-tarsometatarsal joint resulting from symmetrical paralysis of the posterior limbs $[88,89]$. In addition, septicemia may occur with the appearance of fibrinoid pericarditis, hepatitis, and splenomegaly, which can progress to death [90]. Importantly, pathogenic strains are able to colonize the gut of birds in earlier development states compared with commensal strains, which has been attributed as an important driver for the occurrence of the disease [88].

On the other hand, E. faecalis has been associated with omphalitis and yolk sacculitis followed by sepsis and death of chicks in the first week of life, which may or may not be associated with Escherichia coli. Surviving animals may develop valve endocarditis and die in the chronic phase of the infection [86].

Enterococcus spp. can easily acquire resistance to antimicrobials and, therefore, play a central role in its dissemination [86]. Pathogenic E. cecorum strains are more resistant to antimicrobials than commensals [90]. Vancomycin-resistant Enterococcus spp. strains have been associated with economic losses in animal production and also with nosocomial diseases in humans [91-93].

Studies performed between 2014 and 2017 identified the presence of Enterococci species in broilers, laying hens [74,

Table 4 Summary of antimicrobial resistance results in Enterococcus spp. isolated from poultry published in the last 5 years, within the five continents.

\begin{tabular}{|c|c|c|c|c|c|}
\hline Study & Region & Reference & Publishing year & No. of isolates & Resistance profile (\%) \\
\hline 1 & Africa & Ngbede et al. & 2016 & 53 & $\begin{array}{l}\text { AMP }(43,4), \text { C }(9,4), \text { CIP }(11,3), \text { ERY }(73,5), \text { GM }(47,1) \text {, } \\
\text { QD }(9,4), \operatorname{RIF}(15,1), S(47,1), \mathrm{T}(81,1), \operatorname{VAN}(0)\end{array}$ \\
\hline 2 & North America & Kilonzo-Nthenge et al. & 2015 & 132 & $\begin{array}{l}\text { AK (19,7), AMC (10,6), AMP }(14,4), \text { AZI }(6,8), \text { C (3), CEC } \\
\text { (3), ERY }(62,9), \text { FOX }(7,6), \text { KA }(47), \text { P }(52,3), S(81,8), T \\
(44,7)\end{array}$ \\
\hline 3 & North America & Tyson et al. & 2017 & 5455 & $\begin{array}{l}\text { C }(0,3), \text { CIP }(17,8), \text { DAP }(1,9), \text { ERY }(28,1), \text { GM }(6,6), \text { KA } \\
(19,8), \text { LZD }(0,1), \text { NIT }(24,7), \text { P }(13,3) \text {, QD }(20,5), \text { S } \\
(16,6), \text { T }(60) \text {, TGC }(0,1), \text { TYL }(27,2) \text {, VAN }(0)\end{array}$ \\
\hline \multirow[t]{2}{*}{4} & \multirow[t]{2}{*}{ South America } & \multirow[t]{2}{*}{ Donado-Godoy et al. } & \multirow[t]{2}{*}{2014} & E. faecalis 121 & AMP (0), CIP (32), ERY (86), VAN (2) \\
\hline & & & & E. faecium 60 & $\operatorname{AMP}(0), \operatorname{CIP}(33), \operatorname{ERY}(62), \mathrm{QD}(60), \operatorname{VAN}(0)$ \\
\hline 5 & South America & Cavaco et al. & 2017 & E. faecalis 40 & $\begin{array}{l}\mathrm{C}(2,5), \mathrm{CIP}(2,5), \mathrm{ERY}(7,5) \mathrm{FFC}(2,5), \mathrm{GM}(2,5), \mathrm{KA}(2,5), \\
\operatorname{LZD}(7,5), \mathrm{S}(5), \mathrm{T}(7,5), \mathrm{TZD}(7,5)\end{array}$ \\
\hline 6 & South America & Braga et al. & 2017 & E. faecalis 12 & $\begin{array}{l}\operatorname{AMP}(0), \operatorname{AMX}(0), \operatorname{BAC}(0), \operatorname{CEF}(8,3), \operatorname{GM}(33,3), \text { NEO } \\
(25), \operatorname{PNV}(0), \operatorname{VAN}(8,3)\end{array}$ \\
\hline 7 & Asia & Usui et al. & 2014 & E. faecalis 117 & $\begin{array}{l}\text { AMP (0), C }(27,4), \text { ENR }(17,9), \text { ERY }(70,9), \text { GM }(11,1), \text { KA } \\
(37,6), \text { MY }(73,5) \text {, OT }(69,2), \text { S }(51,3) \text {, VAN }(0)\end{array}$ \\
\hline \multirow[t]{2}{*}{8} & \multirow[t]{2}{*}{ Europe } & \multirow[t]{2}{*}{ Maajost et al. } & \multirow[t]{2}{*}{2015} & E. faecalis 126 & $\begin{array}{l}\text { AMC (0), AMP (0), C (8), CIP (5), ERY (44), GM (44), MY } \\
\text { (99), P (0), T (82), TYL (44), VAN (0) }\end{array}$ \\
\hline & & & & E. faecium 18 & $\begin{array}{l}\text { AMC (17), AMP (28), C (6), CIP (56), ERY (61), GM (72), } \\
\text { MY (72), P (44), T (67), TYL (56), VAN (0) }\end{array}$ \\
\hline 9 & Europe & Stepien-Pysnick & 2016 & 911 & $\begin{array}{l}\text { AMC }(4), \operatorname{AMX}(4,4), \operatorname{DOX}(67,3), \operatorname{ENR}(69,4), \operatorname{FFC}(15,7), \\
\text { MY }(56,1), \text { SXT }(88), \text { TYL }(71,4), \text { VAN }(0,1)\end{array}$ \\
\hline
\end{tabular}

$A K$ amikacin, $A M C$ amoxicillin/clavulanic acid, $A M P$ ampicillin, $A M X$ amoxicillin, $A Z I$ azithromycin, $B A C$ bacitracin, $C$ chloramphenicol, $C E C$ cefaclor, $C E F$ ceftiofur, $C I P$ ciprofloxacin, $D A P$ daptomycin, $D O X$ doxycycline, $E N R$ enrofloxacin, $E R Y$ erythromycin, $F F C$ florfenicol, $F O X$ cefoxitin, $G M$ gentamicin, $K A$ kanamycin, $L Z D$ linezolid, $M Y$ lincomycin, $N E O$ neomycin, NIT nitrofurantoin, $O T$ oxytetracycline, $P$ penicillin, $P N V$ penicillin/novobiocin, $Q D$ quinupristin/dalfopristin, $R I F$ rifampicin, $S$ streptomycin, $S X T$ sulfamethoxazole/trimethoprim, $T$ tetracycline, $T G C$ tigecycline, $T Y L$ tyrosine, $T Z D$ tedizolid, VAN vancomycin 
94-97], and chicken meat [98-100], with frequencies ranging from 30.7 to $92 \%$. High levels of resistance (Table 4) were found against drugs belonging to the class of aminoglycosides (streptomycin, 81.8-5\%), tetracyclines (doxycycline, 67.3\%; tetracycline, $82-7.5 \%$ ), and quinolones (ciprofloxacin 97-2.5\%; enrofloxacin, 69-17.9\%). Vancomycin resistance was low (2-0.1\%), with higher levels observed in isolates from chickens affected with vertebral osteomyelitis [101].

\section{Escherichia coli}

Escherichia coli (E. coli), a Gram-negative species belonging to the Enterobacteriaceae family, is of particular importance in the human-animal-environment triad. This species is often studied as a marker for antimicrobial resistance, mainly because of its wide distribution and its capacity to harbor several resistance genes in mobile genetic elements, therefore serving as a source of antimicrobial resistance genes to pathogenic strains [25, 102, 103]. In domestic birds, avian pathogenic $E$. coli (APEC) are causative agents of colibacillosis [104-106]. The number of serotypes causing the disease has been increasing [107], although $\mathrm{O} 1$ and O78 remain as the most commonly detected serovars [104].

Colibacillosis is a complex local or systemic syndrome, in which the pathogen is easily transmitted orally, by inhalation or vertical route $[108,109]$. E. coli containing several virulence genes are shown to lead to persistent and severe clinical diseases in birds [107]. In general, it is considered an opportunistic infection, occurring after the immune response becoming reduced due to stressful situations to the animal, immunosuppression, co-infections, and environmental problems (e.g., excess of ammonia), among others. However, more recently it has also been considered a primary pathogen that causes high economic loss [104, 109]. As for other bacteria species, its epidemiology is complex. Although pathogenic $E$. coli can be introduced onto the farm by different routes, the contact with wild birds, insects, and rodents [108] is of special importance.

The incubation period is short, and birds can be asymptomatic and remain as such until death; in case of coli septicemia, birds become apathetic or moribund [108]. Clinical signs vary according to the syndrome, but the different conditions can result in localized anatomopathological changes, such as coliform omphalitis, coliform cellulitis, swollen head syndrome, and salpingoperitonitis in adults, or systemic such as colisepticemia, respiratory colisepticemia (aerosaculitis, chronic respiratory and complicated chronic respiratory diseases), osteoarthritis, synovitis, and coligranuloma (Hjarre's disease). They can lead to productive losses, ranging from rejects and carcass condemnation to death [108, 109]. Young birds are more susceptible to the pathogen, and high mortality rates are observed in embryos [108].
The success of vaccines has been challenged by the extensive number of serotypes. Therefore, the control of colibacillosis is very dependent of biosecurity measures [108]. The use of bacteriophages has been shown to help prevent colibacillosis with initial development in the respiratory tract and air sacs [110], and in ovo administration of bacteriophages showed similar effect to treatment with enrofloxacin [111]. However, the use of bacteriophages is limited due to the type, bird age, administration route, dose used, and the fact that the elimination of the bacteria in the host can result in the release of endotoxins that lead to fever and toxic shock [112]. Control of colibacillosis with antimicrobials is a common practice, but there are problems resulting from the acquisition of resistance by microorganisms [112], since resistant strains colonizing the gastrointestinal tract can be transmitted to humans and other animals $[95,113]$.

Table 5 shows the resistance levels of $E$. coli isolates from chickens and chicken meat [76, 114-126]. Some studies reported resistance to aminoglycosides, $\beta$-lactam groups (penicillins, cephalosporins), and fluoroquinolones in all tested isolates.

\section{Staphylococcus aureus}

Staphylococcus aureus (S. aureus) is an opportunistic agent that causes nosocomial diseases, which can lead from mild skin lesions to fatal endocarditis [127]. The greatest concern related to the worldwide spread of $S$. aureus [128] is the emergence of strains of methicillin-resistant $S$. aureus (MRSA), often found in humans and animals [129]. They are commonly isolated from chickens and can be transmitted to humans by direct contact or consumption of meat [130,131]. Between 1998 and 2012, eight human outbreaks attributed to $S$. aureus of poultry origin were reported, resulting in 133 sick people and 19 hospitalizations in the USA [132].

Avian staphylococcosis can result in injuries that lead to economic losses due to decreased production and carcass condemnation. The epidemiology is complex since it is widespread in the environment and in the skin and mucosa of animals and humans [133]. MRSA strains have already been detected in rodents [134], which can introduce multiresistant pathogens in poultry farms [133].

Table 6 summarizes the results of antimicrobial resistance in S. aureus obtained from studies between 2015 and 2018 . The greatest resistances were found for amoxicillin (100\%), amoxicillin-clavulanic acid (80-5\%), ampicillin (100-5.9\%), cefoxitin (100-10.5\%), kanamycin (79.3-5, 2\%), penicillin (100-2.1\%), and tetracycline (91.2-10\%). ST398 was the most detected strain among all isolates described in these studies that originated from chickens [123, 135-137] and chicken meat [138-142]. 
Table 5 Summary of antimicrobial resistance results in Escherichia coli isolated from poultry published in the last 5 years, within the five continents.

\begin{tabular}{|c|c|c|c|c|c|}
\hline Study & Region & Reference & Publishing year & No. of isolates & Resistance profile (\%) \\
\hline 1 & Africa & Chishimba et al. & 2016 & 77 & $\begin{array}{l}\text { AMP (100), C (57,1), CAZ (100), CIP }(48,1) \text {, GM }(37,7), \text { NAL } \\
(48,1) \text {, NOR }(54,5), \text { S }(20,8) \text {, SXT }(41,6) \text {, T }(59,7)\end{array}$ \\
\hline 2 & Africa & Awogbemi et al. & 2018 & 10 & $\begin{array}{l}\text { AMC (100), AMP (90), AMX (100), C (90), ERY (80) GM } \\
\text { (50), OB (80), P (80), S (70), T (90) }\end{array}$ \\
\hline 3 & Africa & Osmam et al. & 2018 & 30 & 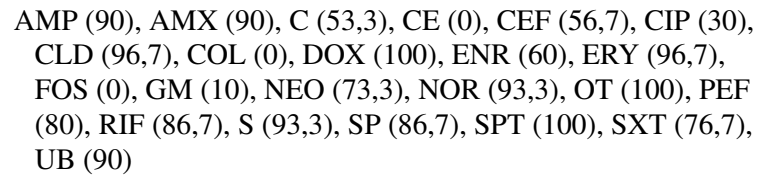 \\
\hline 4 & North America & Johnson et al. & 2017 & 75 & $\begin{array}{l}\text { AMC (21), AMP (41), C (7), CEF (12), CIP (1,3), CRO (13), } \\
\text { FOX (12), GM (55), KA (13), S (47), SUL (63), SXT (12), } \\
\text { T (51) }\end{array}$ \\
\hline 5 & South America & Donado-Godoy et al. & 2014 & 164 & AMP (55), CIP (23), CTX (24) \\
\hline 6 & South America & Koga et al. & 2015 & 39 & $\begin{array}{l}\text { AMC (28,2), AMP (100), C (17,9), CAZ }(5,1) \text { CIP }(43,6), \text { CTX } \\
\text { (94,9), ENR (41), GM }(43,6), \text { KZ }(100), \text { NAL }(74,4), \text { NIT } \\
(10,3), \text { NOR }(30,8), \text { SXT }(33,3), \text { T }(97,4)\end{array}$ \\
\hline 7 & South America & Monte et al. & 2017 & 8 & $\begin{array}{l}\operatorname{AMX}(50), \operatorname{CEF}(87,5), \operatorname{COL}(62,5), \mathrm{CRO}(100), \mathrm{CTX}(100), \\
\operatorname{FOX}(37,5), \mathrm{GM}(62,5), \operatorname{PB}(87,5), \mathrm{SXT}(12,5), \mathrm{T}(50)\end{array}$ \\
\hline 8 & South America & Ferreira et al. & 2018 & 36 & $\begin{array}{l}\text { AMC (100), AZI }(44,4), \text { C }(47,2), \text { CAZ }(66,7) \text {, CIP }(100), \text { CTX } \\
(100) \text {, FEP }(13,9), \text { FOX }(72,2), \text { GM }(30,6), \text { LEV }(94,4) \text {, NAL } \\
(100), \text { SXT }(30,6), \text { T }(88,9)\end{array}$ \\
\hline 9 & Asia & Nguyen et al. & 2015 & 895 & $\begin{array}{l}\text { AK }(5,4), \operatorname{AMC}(47,9), \operatorname{AMP}(86), \text { C }(68,1), \text { CAZ }(2), \text { CIP } \\
(32,5), \text { CRO }(2,5), \text { GM }(19,9), \text { SXT }(69,7), \text { T }(93,4)\end{array}$ \\
\hline 10 & Asia & Brower et al. & 2017 & 1556 & $\begin{array}{l}\operatorname{AMP}(43,8), \mathrm{C}(7,1), \mathrm{CFX}(4), \mathrm{CIP}(39,4), \mathrm{COT}(42,2), \mathrm{GM} \\
(12,9), \operatorname{IMP}(0), \operatorname{NAL}(86,1), \mathrm{NIT}(18,4), \mathrm{T}(47)\end{array}$ \\
\hline 11 & Asia & Amir et al. & 2017 & 450 & $\begin{array}{l}\text { AMX (55,1), AZI }(39,8), \text { C }(56,2), \text { CE }(64,7), \text { CIP }(72,7), \text { CRO } \\
\quad(9,1), \text { GM }(59,6), \text { NAL }(67,6), \text { OT }(99,3), \text { P }(80,7)\end{array}$ \\
\hline 12 & Asia & Hussain et al. & 2017 & 168 & $\begin{array}{l}\text { C (8), CAZ (37), CIP (70), COT (45), FOS (4), GM (32), T } \\
\text { (84) }\end{array}$ \\
\hline 13 & Europe & Hasman et al. & 2015 & 5 & $\begin{array}{l}\text { AK (0), ATM (100), CAZ (100), CIP (20), CTX (100), COL } \\
\text { (100), DOR (0), DOX (40), ETP (0), FEP (0), GM (0), IMP } \\
\text { (0), LEV (20), MEM (0), MH (20), PB (100), SXT (60), T } \\
\text { (0), TGC (0), TIM (40), TZP (0) }\end{array}$ \\
\hline 14 & Europe & Lambrecht et al. & 2017 & 35 & $\begin{array}{l}\text { AMP }(100), \text { AZI }(2,9), \text { C }(42,9), \text { CAZ }(62,9), \text { CIP }(91,4), \text { COL } \\
(2,9), \text { CTX }(65,7), \text { GM }(2,9), \operatorname{MEM}(0), \text { NAL }(54,3), \text { SUL } \\
(80), \text { T }(62,9), \text { TGC }(0), \text { TMP }(74,3)\end{array}$ \\
\hline
\end{tabular}

$A K$ amikacin, $A M C$ amoxicillin/clavulanic acid, $A M P$ ampicillin, $A M X$ amoxicillin, $A Z I$ azithromycin, $C$ chloramphenicol, $C A Z$ ceftazidime, $C E$ cefradine, $C E F$ ceftiofur, $C F X$ cefuroxime, $C I P$ ciprofloxacin, $C L D$ clindamycin, $C O L$ colistin, $C O T$ co-trimoxazole, $C R O$ ceftriaxone, $C T X$ cefotaxime, $D O R$ doripenem, $D O X$ doxycycline, ENR enrofloxacin, ERY erythromycin, ETP ertapenem, FEP cefepime, FLM flumequine, FOS fosfomycin, $F O X$ cefoxitin, $G M$ gentamicin, $I M P$ imipenem, $K A$ kanamycin, $K Z$ cefazoline, $L E V$ levofloxacin, $M E M$ meropenem, $M H$ minocycline, $N A L$ nalidixic acid, $N E O$ neomycin, $N I T$ nitrofurantoin, $N O R$ norfloxacin, $O B$ cloxacillin, $O T$ oxytetracycline, $P$ penicillin, $P B$ polymyxin B, $P E F$ pefloxacin, $R I F$ rifampicin, $S$ streptomycin, $S P$ spermidine, $S P T$ spectinomycin, $S U L$ sulfamethoxazole, $S X T$ sulfamethoxazole/trimethoprim, $T$ tetracycline, $T G C$ tigecycline, $T I M$ ticarcillin/clavulanic acid, $T M P$ trimethoprim, $T Z P$ piperacillin/tazobactam

\section{Poultry-derived products as source of antimicrobial resistance genes to the human microbiota}

Bacteria can acquire resistance against antimicrobial drugs by either spontaneous mutation (in both pre-existing or newly acquired genes) or horizontal gene transfer [143]. Considering the possibility of commensal bacteria to carry and spread ARGs through horizontal gene transfer mechanisms, foodstuffs are potential sources of ARGs to human bacteria. Horizontal gene transfer refers to the transfer of ARGs [144] from resistant to susceptible strains, allowing bacteria to successfully adapt and colonize new environments [11]. Genes coding for antimicrobial resistance can be found in various mobile DNA elements, e.g., plasmids, transposons, genomic islands, and integrons [145]. Horizontal gene transfer can occur through bacterial transformation, transduction, or conjugation. Bacterial transformation is the process by which a recipient bacterium takes up and assimilates free DNA, which carries the resistance genes 
Table 6 Summary of antimicrobial resistance results in Staphylococcus aureus isolated from poultry published in the last 5 years, within the five continents.

\begin{tabular}{|c|c|c|c|c|c|}
\hline Study & Region & Reference & Publishing year & No. of isolates & Resistance profile (\%) \\
\hline 1 & Africa & Chairat et al. & 2015 & 19 & $\begin{array}{l}\text { CIP }(5,2), \text { CLD }(0), \text { ERY }(21), \text { FOX }(10,5), \text { KA }(5,2), \text { OXA } \\
(10,5), \text { P }(94,7), S(0), \text { T }(36,8), \text { TOB }(0)\end{array}$ \\
\hline 2 & Africa & Sallam et al. & 2015 & 288 & $\begin{array}{l}\text { AK }(53,1), \text { AMP }(5,9), \operatorname{AMX}(8,7), C(52,1), \text { CIP }(71,2), \text { ERY } \\
(11,1), \operatorname{GM}(64,2), \text { NET }(70,5), \text { OB }(1), \text { P }(2,1), \operatorname{RIF}(50), S \\
(28,8), \operatorname{SXT}(77,1), \text { T }(18,8), \operatorname{VAN}(87,5)\end{array}$ \\
\hline 3 & Africa & Mkize et al. & 2017 & 29 & $\begin{array}{l}\text { AMP }(27,6), \text { C (69), ERY (62,1), FOX (76), GM }(55,2), \text { KA } \\
(79,3), S(62,1), \text { T }(69), \text { TMP }(58,6), \text { VAN }(14)\end{array}$ \\
\hline 4 & Africa & Awogbemi et al. & 2018 & 10 & $\begin{array}{l}\mathrm{AMC}(80), \operatorname{AMP}(100), \operatorname{AMX}(100), \mathrm{C}(70), \mathrm{GM}(30), \mathrm{OB}(90), \\
\text { P (80), S (50), T (10) }\end{array}$ \\
\hline 5 & North America & Abdalrahman et al. & 2015 & 113 & $\begin{array}{l}\text { AMP (92), AZI }(39,8), \text { C }(2,7), \text { CIP }(23), \text { CLD }(31,9), \text { DOX } \\
\quad(38,1), \text { ERY }(39,8), \text { FOX }(23,9), \text { GM }(28.3), \text { KA }(32,7), \text { OXA } \\
(30,1), \text { P }(57,5), \operatorname{RIF}(8,8), \operatorname{SXT}(16,8), \text { T }(47,8), \text { VAN }(23)\end{array}$ \\
\hline 6 & Asia & Ali et al. & 2017 & 56 & ERY $(80,4)$, GM $(28,6), \operatorname{NEO}(25), P(94,6), \mathrm{T}(82,1)$ \\
\hline 7 & Asia & Ruban et al. & 2017 & MRSA 80 & FOX (67), MET (45), OXA (65) \\
\hline 8 & Asia & Kim et al. & 2018 & 121 & $\begin{array}{l}\text { AMC (5), AMP }(51,2), \text { C }(2,5), \text { CAZ }(2,5), \text { CFN }(1,7), \text { CFX } \\
\text { (1,7), CFZ }(1,7), \text { CIP }(33,9), \text { CLD }(19), \text { CTX }(1,7), \text { DOX } \\
\text { (20,7), ERY }(20,7), \text { FEP }(1,7), \text { GM }(19), \text { KA }(24,7), \text { P }(51,2), \\
\text { RIF }(2,5), \text { SXT }(0,8), T(38,8)\end{array}$ \\
\hline 9 & Europe & Kraushaar et al & 2016 & 68 & $\begin{array}{l}\text { C }(2,9), \text { CIP }(39,7), \text { CLD }(88,2), \text { ERY }(85,3), \text { FD }(2,9), \text { FOX } \\
(100), \text { GM }(2,9), \text { KA }(22,1), \text { P }(100), \text { QD }(80,9), \text { S }(27,9), \text { SUL } \\
(1,5), \text { T }(91,2) \text {, TIA }(63,2), \text { TMP }(73,5)\end{array}$ \\
\hline
\end{tabular}

$A K$ amikacin, $A M C$ amoxicillin/clavulanic acid, $A M P$ ampicillin, $A M X$ amoxicillin, $A Z I$ azithromycin, $C$ chloramphenicol, $C A Z$ ceftazidime, $C F N$ cephalothin, $C F X$ cefuroxime, $C F Z$ cefazoline, $C I P$ ciprofloxacin, $C L D$ clindamycin, $C T X$ cefotaxime, $D O X$ doxycycline, $E R Y$ erythromycin, $F E P$ cefepime, $F D$ fusidic acid, $F O X$ cefoxitin, $G M$ gentamicin, $K A$ kanamycin, $M E T$ methicillin, $N E O$ neomycin, $N E T$ netilmicin, $O B$ cloxacillin, $O X A$ oxacillin, $P$ penicillin, $Q D$ quinupristin/dalfopristin, $R I F$ rifampicin, $S$ streptomycin, $S U L$ sulfamethoxazole, $S X T$ sulfamethoxazole/trimethoprim, $T$ tetracycline, TIA tiamulin, TMP trimethoprim, TOB tobramycin, VAN vancomycin

from the environment [146]. Bacterial transduction involves the transfer of DNA from bacteriophages to bacteria [146]. Plasmid transfer is probably the most frequent mechanisms of horizontal transfer of resistance genes. It refers to the selftransfer of a conjugative plasmid or transposon to a recipient cell [146]. Conjugative plasmids are the most common vectors for the transmission of antimicrobial resistance genes [143].

Plasmids are autonomously replicating extra-chromosomal DNA molecules that range from $<2$ and $>100 \mathrm{~kb}$ in size [146]. They can confer resistance to one or several classes of antimicrobials, including beta-lactams, aminoglycosides, tetracyclines, phenicols, sulfonamides, trimethoprim, macrolides, and quinolones [147].

The spread of antimicrobial resistance in Gram-negative bacteria has been largely attributed to DNA exchange via conjugation of plasmids carrying ARGs [148]. Multiresistance plasmids can be transferred into a susceptible bacterial host independently of whether there is selection pressure for one or all the resistance genes [146]. Thus, the persistence of a gene conferring resistance to a given antimicrobial could occur without the selection pressure on the gene itself. Following the ban of avoparcin, a glycopeptide antibiotic analogue of vancomycin, the prevalence of vancomycin-resistant $E$. faecium in broilers dropped from $72.7 \%$ in 1995 to $5.8 \%$ in 2000 [149]. However, the prevalence in pigs did not decrease until the use of tylosin was reduced. It was shown that tylosin provided the selective pressure for E. faecium to maintain the vancomycin-resistant vanA-erm(B) plasmid which also carried tylosin resistance genes [149]. This is also known as co-resistance, a mechanism of co-selection, when genes conferring a number of antimicrobial resistance phenotypes are located on the same genetic element such as a plasmid or integron [150]. Another mechanism of co-selection, known as cross-resistance, allows bacteria to survive the effects of more than one drug after acquisition of a given antimicrobial resistance gene or mutation [151].

The surveillance of commensal bacterial in foodstuff carrying antimicrobial resistance genes has been used in surveillance programs as an indicator of the level of antimicrobial resistance. Advances in high-throughput analytical methods can provide valuable information on quali-quantitative assessment of chicken products regarding the levels of ARGs. 


\section{Alternatives to reduce the use of antimicrobials and multidrug-resistant foodborne pathogens in the poultry industry}

As the major risks for human-associated diseases caused by multidrug-resistant pathogens have been linked to the consumption of contaminated food, or direct contact with animals, a thorough investigation of the source of antimicrobial-resistant foodborne pathogens upstream in the production cycles is needed to effectively tackle the problem.

For many pathogens, transmission pathways are often very complex and involve wildlife and the environment as reservoirs. In view of the amount of information available in the literature, this section will focus on the control of Salmonella organisms. A recent investigation of Salmonella recovered from captive wildlife host species and the environment in Ohio, USA, determined that indirect transmission of Salmonella could occur among animal hosts via environmental contamination [152]. The same study reported multidrug-penta-resistant Salmonella types (AmSTTeKmGm), suggesting that the role of wildlife and environment in the transmission of antimicrobial resistance to production animals and humans could be underestimated.

Interventions are typically most cost-effective and practical for the control of multidrug-resistant foodborne pathogens when applied upstream in the food supply chain at the farm level, reducing their occurrence and spread through the food chain.

\section{Pre-harvest control of antimicrobial resistance}

Strategies to prevent human MDR-foodborne pathogens, such as Salmonella, have broadened from pre-harvest control at the farm level to post-harvest control of food products [153]. The problem associated with the occurrence of these pathogens in the poultry industry is multifactorial and requires solutions addressing micro-ecosystems and multiple variables. This can be summarized into four key control strategies, namely, vaccination, testing, flock management and sanitation, and gastrointestinal colonization control [153].

Immune responses triggered by vaccinations can reduce the duration and severity of Salmonella infections in chickens, as well as prevent reinfections. However, it cannot completely prevent infections. Poor sanitation, inadequate vaccine management and environmental stress on the chickens can adversely impact vaccine performance. Vaccines also have limited efficacy against field strains or emerging Salmonella serotypes which are antigenically different from vaccine strains. In response to the dramatic increase in human salmonellosis due to egg-transmitted $S$. Enteritidis, several testing and quality assurance programs for commercial laying flocks have been proposed by government agencies and the private sector. In the USA, a combination of environmental sampling, serologic testing, and bacteriological culturing of birds has been employed. The National Poultry Improvement Plan (NPIP) was designed to be a cooperative industry, state, and federal testing and monitoring program to eliminate some poultry diseases including $S$. Pullorum and $S$. Enteritidis. However, testing retains a degree of uncertainty and has limited value in predicting or responding to emerging reservoirs of Salmonella infection or serotypes. Effective biosecurity and hygiene practices as part of flock management and sanitation is crucial, since all other measures would fail if these were not executed appropriately. Effective biosecurity and hygiene practices could be further elaborated upon to include disinfection practices, pest controls, animal, person and vehicle movements, feed, water, and sources of poultry.

\section{Gastrointestinal colonization control of foodborne pathogens}

There are various products promoted as feed additives or treatments that not only improve animal health but can also protect birds from Salmonella infections. Some acidic compounds or organic acids have been shown to directly reduce colonization and shedding of Salmonella [154]. Prebiotics are non-digestible feed ingredients that stimulate the growth of one or a limited number of resident beneficial bacterial species in chickens [155]. Competitive exclusion products are gastrointestinal contents of adult poultry given to chicks to establish an adult microflora that is resistant to Salmonella colonization [156]. Probiotics are living microbial feed ingredients that have anti-inflammatory effects and the potential to modify the microbiological ecosystem within the poultry gut to control Salmonella [157]. Bacteriophages, live viruses that attack bacteria, have shown promise in reducing colonization in experimental trials [158], but field trial studies are limited [154]. Phytobiotics may modulate the chicken microbiome similar to antimicrobials [159], prevent the biofilmproduction [160], and prevent gastrointestinal diseases in broilers [161], without causing neither collateral effects to birds [162] nor selection pressure to antimicrobial resistance in bacteria [163]. Finally, potential feed additives, such as flavophospholipol, could have the beneficial effect of reducing both Salmonella shedding and the number of animals carrying Salmonella at slaughter [164]. 


\section{Surveillance programs to control antimicrobial resistance}

Programs addressing the surveillance of antimicrobial resistance in the food chain have been implemented in some countries and are currently under implementation in many others. They are normally focused on the primary production level (pre-harvest) but can also include the surveillance in animal-derived products (post-harvest). Although targeting mainly foodborne zoonotic bacteria, these programs can also include classic zoonotic agents and animal pathogens as well.

In Europe, the basis for the monitoring of antimicrobial resistance in the food chain was established in 2003 by the Directive on the monitoring of zoonoses and zoonotic agents (Decision 2003/99/EC, 2003). Since then, monitoring has been implemented by means of the legislative authority of the European Commission under the scientific advice of the European Food Safety Agency (EFSA). Detailed information on the microbiological criteria applied to foodstuffs can be found in the Commission Regulation 2005/2073/EC (https://eur-lex.europa.eu/legalcontent/EN/ALL/?uri=CELEX\%3A32005R2073). Efforts towards the standardization of targeted bacteria, samplings procedures, antimicrobials to be used, and their respective cut-off values have been implemented through the Commission Decision 2007/516/EC and Decision 2013/652/EU and were guided by important reports published by EFSA [165-168] providing valuable information for the establishment of the targeted animal populations or food categories and the bacterial hazards. Salmonella surveillance in laying hens, broiler chickens, and turkeys are mandatory in the National Control Programs of all European member states, enabling retrospective analysis of antimicrobial resistance in these isolates. Among other foodstuff, fresh poultry has been monitored for ESBL-, AmpC-, or cabapenemase-producing E. coli (Decision 2013/652/EU, 2013).

\section{National monitoring systems: the US NARMS and the Brazilian PAN-BR}

In USA, the National Antimicrobial Resistance Monitoring System (NARMS) is the surveillance system tracking antimicrobial resistance in foodborne pathogens from different sources, including poultry and chicken products. NARMS was established in 1996 after an expert panel convened by the US Food and Drug Administration (FDA) recommended, in 1994, establishing a national surveillance system to monitor resistance among selected enteric bacteria of animals that can cause disease in humans [169-171].
NARMS is a collaborative effort of three federal agencies, CDC, FDA, and the United States Department of Agriculture (USDA), as well as state and local health departments in all 50 states. It was designed to help assess the consequences to human health arising from the use of antimicrobial drugs in food animal production with a view towards mitigation [172]. The main goals of NARMS are to monitor trends in antimicrobial resistance among enteric bacteria from humans, retail meats, and animals, in addition to disseminate timely information on antimicrobial resistance in pathogenic and commensal organisms to stakeholders in the USA and abroad to promote interventions that reduce resistance among foodborne bacteria. Moreover, other goals include encouraging research to better understand the emergence, persistence, and spread of antimicrobial resistance and to provide data that assist FDA in making decisions related to the approval of safe and effective antimicrobial drugs for animals [173].

Since 2016, under the coordination of the Ministry of Health, Brazil has been implementing its National Action Plan (PAN-BR). The Plan is also in line with the Global Action Plan, defined by the tripartite alliance among the World Health Organization (WHO), the OIE, and the Food and Agriculture Organization (FAO), on the "One Health" concept and involves coordination with the Brazilian Ministry of Health, the Health Regulatory Agency (ANVISA), the Ministry of Agriculture, Livestock, and Food Supply (MAPA), the Ministry of Science, Technology, Innovations and Communications (MCTIC), the Ministry of Cities, the Ministry of Education, and the Ministry of the Environment [174]. In May 2018, MAPA published the National Action Plan on Antimicrobial Resistance in Agriculture (PAN-BR Agro) which has been integrated into the PAN-BR.

The PAN-BR Agro presents eight main objectives, 15 strategic interventions, and 21 activities to be implemented up to 2022 [175]. The plan targets health education, epidemiological studies, surveillance and monitoring of antimicrobial use, strengthening infection prevention and implementation of control measures, and promotion of antimicrobial rational use in animals. It can be expected that the data gaps on antimicrobial use will be solved by these activities. Moreover, the regulation of antimicrobial use, such as the need of veterinary prescriptions, the research of alternatives for antimicrobials used as growth promoters, and education programs will contribute to the prudent use of antimicrobials. Some of the activities include several workshops, the implementation of surveillance system to monitor AMR in bacteria recovered in official pathogen monitoring programs, and development of the monitoring program on antimicrobial use in animals, among others [176]. 


\section{Judicious use of medically important antimicrobials in animal agriculture}

The WHO has reiterated guiding principles to manage antimicrobial resistance in food animals through measures such as enhanced surveillance and better animal husbandry. Better animal husbandry practices include phasing out the use of medically important antibiotics for the treatment of humans as performance enhancers in animal production. Following joint workshops among the WHO, OIE, and FAO on non-human antimicrobial usage and antimicrobial resistance, OIE has developed standards and guidelines to address antimicrobial resistance issues including the responsible and prudent use of antimicrobials and the development of surveillance and monitoring programs for antimicrobial resistance. In 2005, the Codex Alimentarius Commission issued a code of practice to countries in order to mitigate antimicrobial resistance. In response to the abuse and misuse of antimicrobials in the USA, the Food and Drug Administration (FDA) developed strategies outlined under the guidance document \#209 on "The Judicious Use of Medically Important Antimicrobial Drugs in Food-Producing Animals." Medically important antimicrobial drugs refer to antimicrobial drugs that are important for human therapeutic use. The two guiding principles are that "the use of medically important antimicrobials in food-producing animals should be limited to those uses that are considered necessary for assuring animal health" and "the use of medically important antimicrobial drugs in food-producing animals should be limited to those uses that include veterinary oversight or consultation."

While legislations and initiatives to limit antimicrobials except for therapy in food-producing animals could be put in place, it seems likely that such changes alone would not solve the problem of antimicrobial resistance. The American Veterinary Medical Association (AVMA) highlighted that the contribution of antimicrobial use in animal production to the global dissemination of antimicrobial resistance is probably limited [177]. Denmark banned the use of several antimicrobial growth promoters in food animals from 1994 to 1999 , and a voluntary ban on the use of cephalosporins in pig production was implemented in 2010. According to the Danish Integrated Antimicrobial Resistance Monitoring and Research Programme (DANMAP) report for 2013, the prevalence of antimicrobial-resistant bacteria remained constant or on the rise [178]. The report stated that $S$. Typhimurium isolates among Danish pigs exhibited high levels (range 33-47\%) of resistance to ampicillin, streptomycin, sulfonamide, and tetracycline. This co-resistance to four antimicrobial classes refers to the ASSuT profile and could be seen alone or together with resistance to other antimicrobial classes. Resistance to tetracycline increased from 2012 to 2013, while resistances to other antimicrobial agents were similar to levels reported in 2012 [178, 179]. The level of multidrug-resistance among E. coli isolates in Danish broiler chickens and broiler meat has more than doubled within the past 5 years, reaching $16-18 \%$ in 2013 [178]. It was presumed to be driven by an increased therapeutic use of tetracycline in poultry production as subtherapeutic use was banned. There were no significant changes in levels of resistance from of Salmonella infections in humans between 2009 and 2013. In the 10-year period from 2004 to 2013, resistance in $E$. coli human blood isolates to 2 nd generation cephalosporins, ciprofloxacin, and aminoglycoside increased steadily [178]. While it is crucial to ban important antimicrobials in animal production, the Danish experience showed that further approaches are needed not only to reduce foodborne pathogens in animal-derived foods but also the transmission of antimicrobial resistance.

There will be or already are stricter rules or bans on antibiotic growth promoters globally, although it is recognized that there cannot be a total ban on antibiotic use in food animals, at the expense of dramatic adverse health consequences on animals and limitation of tools at the disposal of veterinarians [180].

A solution suggested in stewardship bootcamps for and against the use of antimicrobials in food animals [181] is the use of alternative feed additives that could reduce foodborne pathogen carriage and shedding, promote growth, and reduce the incidence of antimicrobial-resistant bacteria in the gut of food animals [182].

\section{The One Health approach to mitigate antimicrobial resistance in the globalized world}

Although there is a consensus that actions must be taken to reduce the emergence and spread of antimicrobial resistance in livestock, those actions must consider key premises:

1) Antimicrobial resistance is an inevitable biological phenomenon in bacteria that is accelerated by antimicrobial use selective pressure. The actions should address the critical aspects of antimicrobial resistance to human, animals, and the associated ecosystem. The alternatives to control antimicrobial resistance need to be supported by scientific-based knowledge.

2) The animal industry plays a key role in the global food supply. Fighting antimicrobial resistance need to consider economically feasible alternatives that warrant the success of the industries and the sustainable development of the regions where they are located.

3) All sectors of the society, including the decision-makers in the companies, must understand that antimicrobial resistance is a critical topic for the present and future 
of the human civilization. If this is somehow difficult to be grabbed, the companies' lack of commitment on the reduction of antimicrobial-resistant could jeopardize the success of their business.

4) Governments must understand that fighting antimicrobial resistance requires coordinated efforts with the private sector to promote disruptive shifts. That requires an adequate environment for research, development actions, and cost compensation.

5) There is no villain nor magic bullet for the control of antimicrobial resistance. Its mitigation depends on the coordinate multidisciplinary efforts and strengthens capacity building and education. The One Health approach must be embraced as a disruptive platform to tackle antimicrobial resistance and other complex problems.

As explained in the previous sections of this manuscript, antimicrobial resistance is very complex multi-branched problem that require actions at the human, animal, and environmental levels.

Awareness (or lack thereof) is growing on the overlap of individual, regional, and global public health, as well as the health of humans, animals, and the environment [183]. The "One Health" concept involves an interdisciplinary, cooperative approach and is captured in this statement: "collaborative efforts of multiple disciplines, working locally, nationally and globally, to reach optimal health for people, animals and the environment." [184] The concept of "One Health" or "One Medicine" is not new. It was first mentioned by Dr. Calvin Schwabe who recognized that collaboration between human and veterinary professionals is needed to control zoonotic diseases [185].

Following the 2015 World Health Assembly, a global action plan on AMR was adopted [186]. The plan underscores the strong collaboration between the WHO, FAO, and OIE to work with United Nations to combat AMR at the political level. The objective was to have multi-sectorial national action plans by 2017. AMR is also only one of three priority areas that the tripartite organizations have agreed to work on, in addition to rabies and avian influenza. The WHO recommended an overall reduction in the use of medically important antimicrobials in food-producing animals, as well as a complete restriction in the use of such antimicrobials for growth promotion and disease prevention [187]. The FAO action plan of 2016-2020 focuses on improving awareness, developing surveillance and monitoring capacity, strengthening governance, and promotion of good practices [188]. The plan has since been updated to 2021-2025 to cover research and allocation of resources sustainably. The OIE also announced its strategy on AMR in 2016, covering similar areas, with an addition of encouraging the implementation of international standards. The One Health
Global Leaders Group on antimicrobial resistance (Global Leaders Group) has recently been established, which was a recommendation by the Interagency Coordination Group (AMR) on Antimicrobial Resistance. The United Nations Environment Programme (UNEP) is also slated to join the tripartite to combat AMR. This is a positive move to ensure that the One Health approach and political commitment are maintained.

Interestingly, the "One Health concept" has begun to be incorporated in the animal production systems. For instance, a certification program for animal-derived foodstuff produced according to the One Health principles (One Health Certification) has been recently launched. Additionally, other initiatives such as the One Health Poultry Hub, led by the U.K. Royal Veterinary College (RVC), will concentrate efforts in Bangladesh, Sri Lanka, and Vietnam and will look at why intensification of poultry production increases the risk of infectious disease and identify high-risk behaviors, processes, and environments. It will also test and evaluate novel interventions for disease control. With a GBP19.1 million (US\$2.5 million) funding, the major goals of this hub are to assist in the development of policies for the environmental, economic, and social sustainability of poultry production systems and reduce threats to human and animal health and welfare. Bacterial food poisoning, avian influenza, and antimicrobial resistance are among the key areas for collaborators in the hub.

While such initiatives are welcome, poultry companies need to not only apply the principles of One Health, but they need to communicate this compliance with consumers, in order to build consumer trust. Given the inter-sectorial nature of AMR, the poultry industry also needs to join forces with representatives of other sectors, including wildlife and environmental agencies, as these serve as sentinel for AMR [189].

The antimicrobial resistance is probably the clearest example of an increasing multifaceted problem requiring solutions in One Health. The vision that embraced the antimicrobial resistance with a more heuristic vision, including actions at the different levels such as humans, animals, and the environment, is important, but will not solve or enable the civilization to efficiently tackle the problem. One Health initiatives on antimicrobial resistance must include actions addressing the key factors related to the emergence of AMR: political willingness and education on how we interact with the surrounding environment. While we recognize that much must be done in order to better understand the complexity of AMR, recent epidemiological studies agree that the solution is aligned with the principles of global health promotion, reduction of inequity, and investments on research and development to improve our capacity to understand the problems and propose effective control measures. Importantly, investments on research and development must 
require interdisciplinary approaches involving social scientists, economists, and natural science components. For example, many aspects of the misuse of antimicrobials in human and veterinary medicine, considered key drivers for the emergence of antimicrobial resistance, are related to social behavior.

Lastly, political willingness is of crucial importance, as only coordinate actions among the many organizational levels could resonate.

\section{Final considerations}

In poultry farming, a wide range of bacterial species can infect broiler and layer chickens. As in other sectors, the emergence and dissemination of antimicrobial resistance among those bacteria have been posing a serious threat to the whole society, including the industry itself, because:

1) Avian diseases caused by drug-resistant bacteria are more difficult to be treated, leading to aggravated economic losses. Furthermore, animal-derived products have the potential to carry commensal bacteria harboring important antimicrobial resistance genes. The levels of resistance genes or resistant commensal bacteria in foodstuff can be used as non-tariff barriers for exporting countries.

2) Some of these bacteria are zoonotic pathogens, increasing the risk for consumers or workers to also acquire hard-to-treat infections, representing a burden to public health.

Antimicrobial resistance represents a long-term and very complex biological problem; therefore, coordinate and accurate actions are necessary in order to reduce its impact on the present and the future of the human civilization. Such measures need to be performed upon science-based knowledge in order to preserve the economic efficiency of the industry along with the promotion of public health. In this sense, Environmental, Social, and Governance (ESG) integrated initiatives in the poultry industry are encouraged to embrace One Health principals.

Acknowledgements The authors wish to express their thanks for the financial support of Coordenação de Aperfeiçoamento de Pessoal de Nível Superior (CAPES, financial code 001), Conselho Nacional de Pesquisa e Desenvolvimento (CNPq), and Sao Paulo Research Foundation (FAPESP, proc. 2018/21301-2 and 2020/06076-2). Funding for fellowship to conduct studies in Eastern Africa was provided by the NIH Fogarty International Center to WG and SK, Grant no. D43 TW008650.

Author contribution Conceptualization: Wondwossen A. Gebreyes, Celso J. B. Oliveira, Samuel Kariuki, and Oliveiro C. Freitas Neto. Literature search: Mauro M. M. Saraiva, Kelvin Lim, Daniel F. M.
Monte, Patrícia E. N. Givisiez, and Lucas B. R. Alves. Draf preparation: Mauro M. M. Saraiva, Kelvin Lim, Daniel F. M. Monte, Patrícia E. N. Givisiez, Lucas B. R. Alves, Oliveiro C. Freitas Neto, Celso J. B. Oliveira, and Wondwossen A. Gebreyes. Critical review: Angelo Berchieri Júnior and Samuel Kariuki. Revised version preparation: Wondwossen A. Gebreyes, Celso J. B. Oliveira, Samuel Kariuki, Mauro M. M. Saraiva, Kelvin Lim, Lucas B. R. Alves, Daniel F. M. Monte, Patrícia E. N. Givisiez, Oliveiro C. Freitas Neto, and Angelo Berchieri Júnior. All authors read and approved the final manuscript.

\section{Declarations}

Conflict of interest The authors declare no competing interests.

\section{References}

1. Ritchie H (2017) Meat and dairy production. Our World Data. Published online 2010

2. FAO (2020) Meat market review, overview of global meat market developments in 2019

3. OECD/FAO (2020) Meat. In: OECD-FAO agricultural outlook 2020-2029. OECD Publishing

4. FAO (2020) Food outlook - biannual report on global food markets - November 2020

5. United Nations, Department of Economic and Social Affairs PD (2019) World population prospects 2019: highlights (ST/ESA/ SER.A/423)

6. FAO (2011) Mapping suppying and demand for animal-source foods to 2030

7. McEwen SA, Collignon PJ (2018) Antimicrobial resistance: a One Health perspective. Microbiol Spectr. 6(2):521-527

8. Collignon PJ, McEwen SA (2019) One Health - its importance in helping to better control antimicrobial resistance. Trop Med Infect Dis. 4(1):22

9. D'Costa VM, King CE, Kalan L, Morar M, Sung WW, Schwarz C, Froese D, Zazula G, Calmels F, Debruyne R, Golding GB, Poinar HN, Wright GD (2011) Antibiotic resistance is ancient. Nature. 477(7365):457-461

10. Aarestrup FM (2005) Veterinary drug usage and antimicrobial resistance in bacteria of animal origin. Basic Clin Pharmacol Toxicol 96(4):271-281

11. Aarestrup FM, Wegener HC, Collignon P (2008) Resistance in bacteria of the food chain: epidemiology and control strategies. Expert Rev Anti Infect Ther 6(5):733-750

12. World Bank (2017) Drug-resistant infections: a threat to our economic future. World Bank

13. O’Neill J (2016) Tackling drug-resistant infections globally: final report and recommendations. HM Gov Welcome Trust UK. Published online 2018

14. Temkin E, Fallach N, Almagor J, Gladstone BP, Tacconelli E, Carmeli Y (2018) Estimating the number of infections caused by antibiotic-resistant Escherichia coli and Klebsiella pneumoniae in 2014: a modelling study. Lancet Glob Heal 6:e969-e979

15. Van Boeckel TP, Brower C, Gilbert M, Grenfell BT, Levin SA, Robinson TP, Teillant A, Laxminarayan R (2015) Global trends in antimicrobial use in food animals. Proc Natl Acad Sci 112(18):5649-5654

16. OIE - World Organization for Animal Health (2020) Annual report on antimicrobial agents intended for use in animals - better understanding of the global situation

17. Landoni MF, Albarellos G (2015) The use of antimicrobial agents in broiler chickens. Vet J 205(1):21-27 
18. Page SW, Gautier P (2012) Use of antimicrobial agents in livestock. Rev Sci Tech. 31(1):145

19. Barros R, Vieira SL, Favero A, Taschetto D, Mascarello NC, Cemin HS (2012) Reassessing flavophospholipol effects on broiler performance. Rev Bras Zootec. 41(12):2458-2462

20. Saraiva MMS, Moreira Filho ALB, Freitas Neto OC, Silva NMV, Givisiez PEN, Gebreyes WA, Oliveira CJB (2018) Off-label use of ceftiofur in one-day chicks triggers a short-term increase of ESBL-producing E. coli in the gut. PLoS ONE 13(9):e0203158

21. Wolrd Health Organization (WHO) (2017) Critically important antimicrobials for human medicine: ranking of antimicrobial agents for risk management of antimicrobial resistance due to non-human use. Published online 2017

22. Baron S, Jouy E, Larvor E, Eono F, Bougeard S, Kempf I (2014) Impact of third-generation-cephalosporin administration in hatcheries on fecal Escherichia coli antimicrobial resistance in broilers and layers. Antimicrob Agents Chemother 58:5428-5434

23. Garcia-Migura L, Hendriksen RS, Fraile L, Aarestrup FM (2014) Antimicrobial resistance of zoonotic and commensal bacteria in Europe: the missing link between consumption and resistance in veterinary medicine. Vet Microbiol 170:1-9

24. Gibbons JF, Boland F, Egan J, Fanning S, Markey BK, Leonard FC (2016) Antimicrobial resistance of faecal Escherichia coli isolates from pig farms with different durations of in-feed antimicrobial use. Zoonoses Public Health 63(3):241-250

25. Nhung NT, Cuong NV, Thwaites G, Carrique-Mas J (2016) Antimicrobial usage and antimicrobial resistance in animal production in Southeast Asia: a review. Antibiotics 5:37

26. Sarkar P, Gould IM (2006) Antimicrobial agents are societal drugs: how should this influence prescribing? Drugs 66(7):893-901

27. Mathew AG, Cissell R, Liamthong S (2007) Antibiotic resistance in bacteria associated with food animals: a United States perspective of livestock production. Foodborne Pathog Dis 4(2):115-133

28. Gorbach SL (2001) Antimicrobial use in animal feed - time to stop. N Engl J Med 345(16):1202-1203

29. Rashmi S, Chaman LS, Bhuvneshwar K (2005) Antibacterial resistance: current problems and possible solutions. Indian J Med Sci 59:120-129

30. Nisha AR (2008) Antibiotic residues - a global health hazard. Vet World 1:375-377

31. Sajid A, Kashif N, Kifayat N, Ahmad S (2016) Detection of antibiotic residues in poultry meat. Pak J Pharm Sci 29:1691-1694

32. Bacanlı M, Başaran N (2019) Importance of antibiotic residues in animal food. Food Chem Toxicol 125:462-466

33. Menkem ZE, Ngangom BL, Tamunjoh SSA, Boyom FF (2019) Antibiotic residues in food animals: public health concern. Acta Ecol Sin 39:411-415

34. Gould IM (2008) The epidemiology of antibiotic resistance. Int J Antimicrob Agents 32:S2-S9

35. Monte DF, Lincopan N, Fedorka-Cray P, Landgraf M (2019) Current insights on high priority antibiotic-resistant Salmonella enterica in food and foodstuffs: a review. Curr Opin Food Sci 26:35-46

36. Collignon P, Beggs JJ, Walsh TR, Gandra S, Laxminarayan R (2018) Anthropological and socioeconomic factors contributing to global antimicrobial resistance: a univariate and multivariable analysis. Lancet Planet Health 2:e398-e405

37. Grant A, Hashem F, Parveen S (2016) Salmonella and Campylobacter: antimicrobial resistance and bacteriophage control in poultry. Food Microbiol 53:104-109

38. da Cunha-Neto A, Carvalho LA, Carvalho RCT, dos Prazeres RD, Mano SB, de Souza Figueiredo EE, Conte-Junior CA (2018) Salmonella isolated from chicken carcasses from a slaughterhouse in the state of Mato Grosso, Brazil: antibiotic resistance profile, serotyping, and characterization by repetitive sequencebased PCR system. Poult Sci 97(4):1373-1381

39. Dhanani AS, Block G, Dewar K, Forgetta V, Topp E, Beiko RG, Diarra MS (2015) Genomic comparison of non-typhoidal Salmonella enterica serovars Typhimurium, Enteritidis, Heidelberg, Hadar and Kentucky isolates from broiler chickens. PLoS ONE 10(6):e0128773

40. Kaakoush NO, Castaño-Rodríguez N, Mitchell HM, Man SM (2015) Global epidemiology of Campylobacter infection. Clin Microbiol Rev 28(3):687-720

41. Sahin O, Kassem II, Shen Z, Lin J, Rajashekara G, Zhang Q (2015) Campylobacter in poultry: ecology and potential interventions. Avian Dis 59(2):185-200

42. Bortolaia V, Espinosa-Gongora C, Guardabassi L (2016) Human health risks associated with antimicrobial-resistant enterococci and Staphylococcus aureus on poultry meat. Clin Microbiol Infect 22(2):130-140

43. Boulianne M, Arsenault J, Daignault D, Archambault M, Letellier A, Dutil L (2016) Drug use and antimicrobial resistance among Escherichia coli and Enterococcus spp. isolates from chicken and turkey flocks slaughtered in Quebec, Canada. Can J Vet Res 80(1):49-59

44. Katakweba AA, Muhairwa AP, Lupindu AM, Damborg P, Rosenkrantz JT, Minga UM, Mtambo MMA, Olsen JE (2018) First report on a randomized investigation of antimicrobial resistance in fecal indicator bacteria from livestock, poultry, and humans in Tanzania. Microb Drug Resist 24(3):260-268

45. Simoneit C, Burow E, Tenhagen B-A, Käsbohrer A (2015) Oral administration of antimicrobials increase antimicrobial resistance in E. coli from chicken-a systematic review. Prev Vet Med 118(1): $1-7$

46. Nworie A, Onyema AS, Okekpa SI, Elom MO, Umoh NO, Usanga VU, Ibiam GA, Ukwah BN, Nwadi LC, Ezeruigbo C, Olayinka BO, Smith TC (2017) A novel methicillin-resistant Staphylococcus aureus $\mathrm{t} 11469$ and a poultry endemic strain t002 (ST5) are present in chicken in Ebonyi State, Nigeria. Biomed Res Int 2017:2017

47. WHO - World Health Organisation (2018) Salmonella (nontyphoidal) http://www.who.int/news-room/fact-sheets/detail/ salmonella-(non-typhoidal). Accessed 11 Dec 2020

48. Issenhuth-Jeanjean S, Roggentin P, Mikoleit M, Guibourdenche M, de Pinna E, Nair S, Fields PI, Weill FX (2014) Supplement 2008-2010 (no. 48) to the white-Kauffmann-Le minor scheme. Res Microbiol 165(7):526-530

49. Bae D, Cheng C-M, Khan AA (2015) Characterization of extended-spectrum $\beta$-lactamase (ESBL) producing non-typhoidal Salmonella (NTS) from imported food products. Int J Food Microbiol 214:12-17

50. Antunes P, Mourão J, Campos J, Peixe L (2016) Salmonellosis: the role of poultry meat. Clin Microbiol Infect 22(2):110-121

51. Nhung NT, Van NTB, Van Cuong N, Duong TTQ, Nhat TT, Hang TTT, Nhi NTH, Kiet BT, Hien VB, Ngoc PT, Campbell J, Thwaites G, Carrique-Mas J (2018) Antimicrobial residues and resistance against critically important antimicrobials in nontyphoidal Salmonella from meat sold at wet markets and supermarkets in Vietnam. Int J Food Microbiol 266:301-309

52. Hoffmann S, Batz MB, Morris JG (2012) Annual cost of illness and quality-adjusted life year losses in the United States due to 14 foodborne pathogens. J Food Prot 75(7):1292-1302

53. Agada GOA, Abdullahi IO,

54. Scharff RL, Besser J, Sharp DJ, Jones TF, Peter G-S, Hedberg CW (2016) An economic evaluation of PulseNet: a network for foodborne disease surveillance. Am J Prev Med 50(5):S66-S73

55. Gast RK, Porter Jr RE (2020) Salmonella infections. Dis Poult. Published online 2020:717-753 
56. Psifidi A, Russell KM, Matika O, Sánchez-Molano E, Wigley P, Fulton JE, Stevens MP, Fife MS (2018) The genomic architecture of fowl typhoid resistance in commercial layers. Front Genet 9:519

57. de Sousa E, Werther K, Berchieri Junior A, Almeida AM, Ardisson FA, Silva AC, Candioto CG, Fernandes SA (2013) Experimental infection of one-day-old chicks with Salmonella Serotypes Previously isolated from poultry facilities, wild birds, and swine. Brazilian J Poult Sci 15(4):301-305

58. Markos T, Abdela N (2016) Epidemiology and economic importance of pullorum disease in poultry: a review. Published online 2016

59. Celis-Estupiñan ALP, Batista DFA, Cardozo MV, Souza AIS, Rodrigues Alves LB, Almeida AM, Barrow PA, Freitas Neto OC (2017) Further investigations on the epidemiology of fowl typhoid in Brazil. Avian Pathol 46(4):416-425

60. Álvarez-Fernández E, Alonso-Calleja C, García-Fernández C, Capita R (2012) Prevalence and antimicrobial resistance of Salmonella serotypes isolated from poultry in Spain: comparison between 1993 and 2006. Int J Food Microbiol 153(3):281-287

61. El-Sharkawy H, Tahoun A, El-Gohary AEGA, El-Abasy M, ElKhayat F, Gillespie T, Kitade Y, Hafez HM, Neubauer H, ElAdawy H (2017) Epidemiological, molecular characterization and antibiotic resistance of Salmonella enterica serovars isolated from chicken farms in Egypt. Gut Pathog 9(1):1-12

62. Hoszowski A, Zajac M, Lalak A, Przemyk P, Wasyl D (2016) Fifteen years of successful spread of Salmonella enterica serovar Mbandaka clone ST413 in Poland and its public health consequences. Ann Agric Environ Med 23(2)

63. Alcaine SD, Warnick LD, Wiedmann M (2007) Antimicrobial resistance in nontyphoidal Salmonella. J Food Prot 70(3):780-790

64. Varma JK, Mølbak K, Barrett TJ, Beebe JL, Jones TF, RabatskyEhr T, Smith KE, Vugia DJ, Chang H-GH, Angulo FJ (2005) Antimicrobial-resistant nontyphoidal Salmonella is associated with excess bloodstream infections and hospitalizations. J Infect Dis 191(4):554-561

65. FDA - Food and Drug Administration (2018). NARMS update: integrated report summary. Published 2020. Accessed February 1, 2020. https://www.fda.gov/animal-veterinary/national-antim icrobial-resistance-monitoring-system/2018-narms-update-integ rated-report-summary (Last accessed on November 5, 2021)

66. CDC. Antibiotic Resistance Threats in the United States (2019). US Department of Health and Human Services, Centres for Disease Control and Prevention; 2019

67. McDermott PF (2005) Antimicrobial Resistance in nontyphoidal Salmonellae. Antimicrob Resist Bact Anim Orig 2005:293-314

68. Gupta A, Fontana J, Crowe C, Bolstorff B, Stout A, Duyne SV, Hoekstra MP, Whichard JM, Barrett TJ, National Antimicrobial Resistance Monitoring System PulseNet Working Group (2003) Emergence of multidrug-resistant Salmonella enterica Serotype Newport Infections Resistant to Expanded-Spectrum Cephalosporins in the United States. J Infect Dis 188(11):1707-1716

69. Carattoli A, Villa L, Feudi C, Curcio L, Orsini S, Luppi A, Pezzotti G, Magistrali CF (2017) Novel plasmid-mediated colistin resistance mcr-4 gene in Salmonella and Escherichia coli, Italy 2013, Spain and Belgium, 2015 to 2016. Euro Surveill. 22(31):30589

70. Silva J, Leite D, Fernandes M, Mena C, Gibbs PA, Teixeira P (2011) Campylobacter spp. as a foodborne pathogen: a review. Front Microbiol 2:200

71. El-Tras WF, Holt HR, Tayel AA, El-Kady NN (2015) Campylobacter infections in children exposed to infected backyard poultry in Egypt. Epidemiol Infect. 143(2):308-315

72. Hermans D, Pasmans F, Messens W, Martel A, Van Immerseel F, Rasschaert G, Heyndrickx M, Deun KV, Haesebrouck F (2012)
Poultry as a host for the zoonotic pathogen Campylobacter jejuni. Vector-Borne Zoonotic Dis. 12(2):89-98

73. Schets FM, Jacobs-Reitsma WF, van der Plaats RQ, Heer LKD, van Hoek AH, Hamidjaja RA, Husman AMR, Blaak H (2017) Prevalence and types of Campylobacter on poultry farms and in their direct environment. J Water Health. 15(6):849-862

74. Van Deun K, Pasmans F, Ducatelle R, Flahou B, Vissenberg K, Martel A, Van den Broeck W, Van Immerseel F, Haesebrouck F (2008) Colonization strategy of Campylobacter jejuni results in persistent infection of the chicken gut. Vet Microbiol. 130(3):285-297

75. Umaraw P, Prajapati A, Verma AK, Pathak V, Singh VP (2017) Control of Campylobacter in poultry industry from farm to poultry processing unit: a review. Crit Rev Food Sci Nutr. 57(4):659-665

76. Donado-Godoy P, Castellanos R, León M, Arevalo A, Clavijo V, Bernal J, León D, Tafur MA, Byrne BA, Smith WA, Perez-Gutierrez E (2015) The establishment of the Colombian Integrated Program for Antimicrobial Resistance Surveillance (COIPARS): a pilot project on poultry farms, slaughterhouses and retail market. Zoonoses Public Hlth. 62(s1):58-69

77. Karikari AB, Obiri-Danso K, Frimpong EH, Krogfelt KA (2016) Multidrug resistant Campylobacter in faecal and carcasses of commercially produced poultry. African J Microbiol Res. 11(7): 1385

78. Kassem II, Kehinde O, Kumar A, Rajashekara G (2016) Antimicrobial-resistant Campylobacter in organically and conventionally raised layer chickens. Foodborne Pathog Dis. 14(1):29-34

79. Vinueza-Burgos C, Wautier M, Martiny D, Cisneros M, Van Damme I, De Zutter L (2017) Prevalence, antimicrobial resistance and genetic diversity of Campylobacter coli and Campylobacter jejuni in Ecuadorian broilers at slaughter age. Poult Sci. 96(7):2366-2374

80. Wieczorek K, Bocian Ł, Osek J (2020) Prevalence and antimicrobial resistance of Campylobacter isolated from carcasses of chickens slaughtered in Poland - a retrospective study. Food Control. 112:107159

81. Han X, Zhu D, Lai H, Zeng H, Zhou K, Zou L, Wu C, Han G, Liu S (2016) Prevalence, antimicrobial resistance profiling and genetic diversity of Campylobacter jejuni and Campylobacter coli isolated from broilers at slaughter in China. Food Control. 69:160-170

82. Panzenhagen PHN, Aguiar WS, da Silva FB, de Almeida Pereira VL, da Costa Abreu DL, dos Prazeres RD, Nascimento ER, de Aquino MHC (2016) Prevalence and fluoroquinolones resistance of Campylobacter and Salmonella isolates from poultry carcasses in Rio de Janeiro, Brazil. Food Control. 61:243-247

83. Kottawatta KSA, Van Bergen MAP, Abeynayake P, Wagenaar JA, Veldman KT, Kalupahana RS (2017) Campylobacter in broiler chicken and broiler meat in Sri Lanka: influence of semi-automated vs. wet market processing on Campylobacter contamination of broiler neck skin samples. Foods 6:105

84. García-Sánchez L, Melero B, Diez AM, Jaime I, Rovira J (2018) Characterization of Campylobacter species in Spanish retail from different fresh chicken products and their antimicrobial resistance. Food Microbiol. 76:457-465

85. Torres C, Alonso CA, Ruiz-Ripa L, León-Sampedro R, Del RC, Coque TM (2018) Antimicrobial resistance in Enterococcus spp. of animal origin. In: Schwarz S, Cavaco LM, Shen J (eds) Antimicrobial resistance in bacteria from livestock and companion animals, 1st edn. Wiley Online Library, London, pp 185-227

86. Borst LB (2020) Streptococcus and Enterococcus. In: Swayne DE (ed) Diseases of poultry, 14th edn. Wiley-Blackwell, Hoboken, NJ, pp 1003-1009

87. Devriese LA, Cauwerts K, Hermans K (2002) Enterococcus cecorum septicemia as a cause of bone and joint lesions 
resulting in lameness in broiler chickens. Vlaams Diergen Tijds. 71:219-221

88. Borst LB, Suyemoto MM, Sarsour AH, Harris MC, Martin MP, Strickland JD, Oviedo EO, Barnes HJ (2016) Pathogenesis of enterococcal spondylitis caused by Enterococcus cecorum in broiler chickens. Vet Pathol. 54:61-73

89. Borst LB, Suyemoto MM, Chen LR, Barnes HJ (2019) Vaccination of breeder hens with a polyvalent killed vaccine for pathogenic Enterococcus cecorum does not protect offspring from enterococcal spondylitis. Avian Pathol. 48:17-24

90. Jung A, Chen LR, Suyemoto MM, Barnes HJ, Borst LB (2018) A review of Enterococcus cecorum infection in poultry. Avian Dis. 62:261-271

91. Khan HA, Ahmad A, Mehboob R (2015) Nosocomial infections and their control strategies. Asian Pac J Trop Biomed. 5:509-514

92. Dolka B, Chrobak-Chmiel D, Makrai L, Szeleszczuk P (2016) Phenotypic and genotypic characterization of Enterococcus cecorum strains associated with infections in poultry. BMC Vet Res. 12:129

93. Dolka B, Chrobak-Chmiel D, Czopowicz M, Szeleszczuk P (2017) Characterization of pathogenic Enterococcus cecorum from different poultry groups: Broiler chickens, layers, turkeys, and waterfowl. PLoS ONE. 12:e0185199

94. Usui M, Ozawa S, Onozato H, Kuge R, Obata Y, Uemae T, Ngoc PT, Heriyanto A, Chalemchaikit T, Makita K, Muramatsu Y, Tamura Y (2014) Antimicrobial susceptibility of indicator bacteria isolated from chickens in southeast Asian countries (Vietnam, Indonesia and Thailand). J Vet Med Sci. 76:685-692

95. Maasjost J, Mühldorfer K, De Jäckel SC, Hafez HM (2015) Antimicrobial susceptibility patterns of Enterococcus faecalis and enterococcus faecium isolated from poultry flocks in Germany. Avian Dis. 59:143-148

96. Ngbede EO, Raji MA, Kwanashie CN, Kwaga JKP (2017) Antimicrobial resistance and virulence profile of enterococci isolated from poultry and cattle sources in Nigeria. Trop Anim Health Prod 49:451-458

97. Stępień-Pyśniak D, Marek A, Banach T, Adaszek Ł, Pyzik E, Wilczyński J, Winiarczyk S (2016) Prevalence and antibiotic resistance of Enterococcus strains isolated from poultry. Acta Vet Hung 64:148-163

98. Kilonzo-Nthenge A, Brown A, Nahashon SN, Long D (2015) Occurrence and antimicrobial resistance of enterococci isolated from organic and conventional retail chicken. J Food Prot 78:760-766

99. Cavaco LM, Bernal JF, Zankari E, Léon M, Hendriksen RS, Perez-Gutierrez E, Aarestrup FM, Donado-Godoy P (2017) Detection of linezolid resistance due to the optrA gene in Enterococcus faecalis from poultry meat from the American continent (Colombia). J Antimicrob Chemother 72:678-683

100. Tyson GH, Nyirabahizi E, Crarey E, Kabera C, Lam C, RiceTrujillo C, Mcdermott PF, Tate H (2018) Prevalence and antimicrobial resistance of enterococci isolated from retail meats in the United States, 2002 to 2014. Appl Environ Microbiol 84:e01902-e01917

101. Braga JFV, Leal CAG, Silva CC, Fernandes AA, Martins NRS, Ecco R (2017) Genetic diversity and antimicrobial resistance profile of Enterococcus faecalis isolated from broilers with vertebral osteomyelitis in Southeast Brazil. Avian Pathol 47:14-22

102. EFSA (2016) The European Union summary report on antimicrobial resistance in zoonotic and indicator bacteria from humans, animals and food in 2014. EFSA. 14:4380

103. Kheiri R, Akhtari L (2016) Antimicrobial resistance and integron gene cassette arrays in commensal Escherichia coli from human and animal sources in IRI. Gut Pathogens. 8:40
104. Collingwood C, Kemmett K, Williams N, Wigley P (2014) Is the concept of avian pathogenic Escherichia coli as a single pathotype fundamentally flawed? Front Vet Sci. 1:1-4

105. Pasquali F, Lucchi A, Braggio S, Giovanardi D, Franchini A, Stonfer M, Manfreda G (2015) Genetic diversity of Escherichia coli isolates of animal and environmental origins from an integrated poultry production chain. Vet Microbiol. 178:230-237

106. Barbieri NL, Nielsen DW, Wannemuehler Y, Cavender T, Hussein A, Yan S, Nolan LK, Logue CM (2017) mcr-1 identified in avian pathogenic Escherichia coli (APEC). PLoS ONE 12:e0172997

107. Carli S, Ikuta N, Lehmann FKM, Silveira VP, Predebon GM, Fonseca ASK, Lunge VR (2015) Virulence gene content in Escherichia coli isolates from poultry flocks with clinical signs of colibacillosis in Brazil. Poult Sci. 94:2635-2640

108. Nolan LK, Vaillancourt JP, Barbieri NL, Logue CM (2020) Colibacilosis. In: Swayne DE (ed) Diseases of Poultry, 14th edn. Wiley-Blackwell, Hoboken, NJ, pp 770-830

109. Guabiraba R, Schouler C (2015) Avian colibacillosis: still many black holes. FEMS Microbiol Lett 362:fnv118

110. Wernicki A, Nowaczek A, Urban-Chmiel R (2017) Bacteriophage therapy to combat bacterial infections in poultry. Virol $\mathrm{J}$. $14: 1-13$

111. Huff WE, Huff GR, Rath NC, Donoghue AM (2009) Critical evaluation of bacteriophage to prevent and treat colibacillosis in poultry. J Ark Acad Sci. 63:93-98

112. Ozaki H, Matsuoka Y, Nakagawa E, Murase T (2017) Characteristics of Escherichia coli isolated from broiler chickens with colibacillosis in commercial farms from a common hatchery. Poult Sci. 96:3717-3724

113. Olsen RH, Bisgaard M, Löhren U, Robineau B, Christensen H (2014) Extended-spectrum $\beta$-lactamase-producing Escherichia coli isolated from poultry: a review of current problems, illustrated with some laboratory findings. Avian Pathol. 43:199-208

114. Hasman H, Hammerum AM, Hansen F, Hendriksen RS, Olesen B, Agers $\varnothing$ Y, Zankari E, Leekitcharoenphon P, Stegger M, Kaas RS, Cavaco LM, Hansen DS, Aarestrup FM, Skov RL (2015) Detection of mcr-1 encoding plasmid-mediated colistin-resistant Escherichia coli isolates from human bloodstream infection and imported chicken meat, Denmark 2015. Euro Surveill. 20(49):30085

115. Koga VL, Rodrigues GR, Scandorieiro S, Vespero EC, Oba A, de Brito BG, de Brito KCT, Nakazato G, Kobayashi RKT (2015) Evaluation of the antibiotic resistance and virulence of Escherichia coli strains isolated from chicken carcasses in 2007 and 2013 from Paraná, Brazil. Foodborne Pathog Dis. 12:479-485

116. Nguyen VT, Carrique-Mas JJ, Ngo TH, Ho HM, Ha TT, Campbell JI, Nguyen TN, Hoang NN, Pham VM, Wagenaar JA, Hardon A, Thai QH, Schultsz C (2015) Prevalence and risk factors for carriage of antimicrobial-resistant Escherichia coli on household and small-scale chicken farms in the Mekong Delta of Vietnam. J Antimicrob Chemother 70:2144-2152

117. Chishimba K, Hang'ombe BM, Muzandu K, Mshana SE, Matee MI, Nakajima C, Suzuki Y (2016) Detection of extended-spectrum beta-lactamase-producing Escherichia coli in market-ready chickens in Zambia. Int J Microbiol. 2016:5275724

118. Amir M, Riaz M, Chang YF, Akhtar S, Yoo SH, Sheikh AS, Kashif M (2017) Impact of unhygienic conditions during slaughtering and processing on spread of antibiotic resistant Escherichia coli from poultry. Microbiol Res. 8:7330

119. Brower CH, Mandal S, Hayer S, Sran M, Zehra A, Patel SJ, Kaur R, Chatterjee L, Mishra S, Das BR, Singh P, Singh R, Gill JPS, Laxminarayan R (2017) The prevalence of extended-spectrum beta-lactamase-producing multidrug-resistant Escherichia coli in poultry chickens and variation according to farming practices in Punjab, India. Environ Health Perspec 125:077015 
120. Hussain A, Shaik S, Ranjan A, Nandanwar N, Tiwari SK, Majid M, Baddam R, Qureshi IA, Semmler T, Wieler LH, Islam MA, Chakravortty D, Ahmed N (2017) Risk of transmission of antimicrobial resistant Escherichia coli from commercial broiler and free-range retail chicken in India. Front Microbiol. 8:2120

121. Johnson JR, Porter SB, Johnston B, Thuras P, Clock S, Crupain M, Rangan U (2017) Extraintestinal pathogenic and antimicrobial resistant Escherichia coli, Including sequence type 131 (ST131), from retail chicken breasts: United States, 2013. Appl Environ Microbiol 83:AEM.02956-16

122. Monte DFM, Mem A, Fernandes MR, Cerdeira L, Esposito F, Galvão JA, Franco BDGM, Lincopan N, Landgraf M (2017) Chicken meat as reservoir of colistin-resistant Escherichia coli carrying mcr- 1 genes in South America. Antimicrob Agents Chemother 61:AAC.02718-16

123. Awogbemi J, Moses A, Ezekiel Olugbenga A (2018) A Survey of antimicrobial agents usage in poultry farms and antibiotic resistance in Escherichia coli and staphylococci isolates from the poultry in Ile-Ife, Nigeria. J Infect Dis Epidemiol. 4:1-8

124. Ferreira JC, Penha Filho RAC, Kuaye APY, Andrade LN, Berchieri Junior A, Darini ALC (2018) Identification and characterization of plasmid-mediated quinolone resistance determinants in Enterobacteriaceae isolated from healthy poultry in Brazil. Infect Genet Evol. 60:66-70

125. Lambrecht E, Van Meervenne E, Boon N, Van De Wiele T, Wattiau P, Herman L, Heyndrickx M, Van Coillie E (2018) Characterization of cefotaxime- and ciprofloxacin-resistant commensal Escherichia coli originating from belgian farm animals indicates high antibiotic resistance transfer rates. Microbial Drug Resist. 24:707-717

126. Osman KM, Kappell AD, Elhadidy M, Elmougy F, ElGhany WAA, Orabi A, Mubarak AS, Dawoud TM, Hemeg HA, Moussa IMI, Hessain AM, Yousef HMY (2018) Poultry hatcheries as potential reservoirs for antimicrobial-resistant Escherichia coli: a risk to public health and food safety. Sci Rep. 8:5859

127. Tong SYC, Davis JS, Eichenberger E, Holland TL, Fowler VG (2015) Staphylococcus aureus infections: epidemiology, pathophysiology, clinical manifestations, and management. Clin Microbiol Rev. 28:603-661

128. Murray S, Pascoe B, Meric G, Mageiros L, Yahara K, Hitchings MD, Friedmann Y, Wilkinson TS, Gormley FJ, Mack D, Bray JE, Lamble S, Bowden R, Jolley KA, Maiden MCJ, Wendlandt S, Schwarz S, Corander J, Fitzgerald JR, Sheppard SK (2017) Recombination-mediated host adaptation by avian Staphylococcus aureus. Genome Biol Evol. 9:830-842

129. Peton V, Le Loir Y (2014) Staphylococcus aureus in veterinary medicine. Infect Genet Evol. 21:602-615

130. Jamrozy DM, Fielder MD, Butaye P, Coldham NG (2012) Comparative genotypic and phenotypic characterisation of methicillin-resistant Staphylococcus aureus ST398 isolated from animals and humans. PLoS ONE. 7:e40458-e40458

131. Verkade E, Kluytmans J (2014) Livestock-associated Staphylococcus aureus CC398: animal reservoirs and human infections. Infect Genet Evol. 21:523-530

132. Chai SJ, Cole D, Nisler A, Mahon BE (2017) Poultry: the most common food in outbreaks with known pathogens, United States, 1998-2012. Epidemiol Infect. 145:316-325

133. Andresen CB (2020) Staphylococcosis. In: Swayne DE (ed) Diseases of poultry, 14th edn. Wiley-Blackwell, Hoboken, NJ, pp 995-1003

134. Himsworth CG, Miller RR, Montoya V, Hoang L, Romney MG, Al-Rawahi GN, Kerr T, Jardine CM, Patrick DM, Tang P, Weese JS (2014) Carriage of methicillin-resistant Staphylococcus aureus by wild urban Norway rats (Rattus norvegicus). PLoS ONE 9(2):e87983
135. Ali Y, Islam MA, Muzahid NH, Sikder MOF, Hossain MA, Marzan LW (2017) Characterization, prevalence and antibiogram study of Staphylococcus aureus in poultry. Asian Pac J Trop Biomed. 7:253-256

136. Kraushaar B, Ballhausen B, Leeser D, Tenhagen BA, Käsbohrer A, Fetsch A (2017) Antimicrobial resistances and virulence markers in methicillin-resistant Staphylococcus aureus from broiler and turkey: a molecular view from farm to fork. Vet Microbiol. 200:25-32

137. Mkize N, Zishiri OT, Mukaratirwa S (2017) Genetic characterisation of antimicrobial resistance and virulence genes in Staphylococcus aureus isolated from commercial broiler chickens in the Durban metropolitan area, South Africa. J S Afr Vet Assoc 88:1-7

138. Abdallah HM, Reuland EA, Wintermans BB, Naiemi N, Koek A, Abdelwahab AM, Ammar AM, Mohamed AA, Vandenbroucke-Grauls CMJE (2015) Extended-spectrum $\beta$-lactamases and/or carbapenemases-producing Enterobacteriaceae isolated from retail chicken meat in Zagazig, Egypt. PLoS ONE. 10:e0136052

139. Chairat S, Gharsa H, Lozano C, Gómez-Sanz E, Gómez P, Zarazaga M, Boudabous A, Torres C, Ben Slama K (2015) Characterization of Staphylococcus aureus from raw meat samples in Tunisia: detection of clonal lineage ST398 from the African Continent. Foodborne Pathog Dis. 12:686-692

140. Sallam KI, Abd-Elghany SM, Elhadidy M, Tamura T (2015) Molecular characterization and antimicrobial resistance profile of methicillin-resistant Staphylococcus aureus in retail chicken. J Food Prot. 78:1879-1884

141. Ruban SW, Babu RN, Abraham RJJ, Senthilkumar TMA, Kumaraswamy P, Rao VA, Porteen K (2017) Prevalence of panton valentine leukocidin $(p v l)$ gene in methicillin resistant Staphylococcus aureus isolated from market samples of chicken meat. Int J Cur Microbiol Appl Sci. 6:2459-2466

142. Kim YB, Seo KW, Jeon HY, Lim SK, Lee YJ (2018) Characteristics of the antimicrobial resistance of Staphylococcus aureus isolated from chicken meat produced by different integrated broiler operations in Korea. Poultry Sci. 97:962-969

143. Boerlin P, Reid-Smith RJ (2008) Antimicrobial resistance: its emergence and transmission. Anim Heal Res Rev. 9(2):115-126

144. Courvalin P (1996) Molecular and epidemiologic aspects of the resistance to antibiotics: example of glycopeptides on enterococci. C R Seances Soc Biol Fil. 190(4):467-469

145. Mark Osborn A, Böltner D (2002) When phage, plasmids, and transposons collide: genomic islands, and conjugative- and mobilizable-transposons as a mosaic continuum. Plasmid. 48(3):202-212

146. Schwarz S, Cloeckaert A, Roberts MC (2005) Mechanisms and spread of bacterial resistance to antimicrobial agents. In: Aarestrup FM (ed) Antimicrobial resistance in bacteria of animal origin, 1st edn. ASM Press, Washington DC, pp 73-98

147. Carattoli A (2009) Resistance plasmid families in Enterobacteriaceae. Antimicrob Agents Chemother. 53(6):2227-2238

148. Carattoli A (2013) Plasmids and the spread of resistance. Int J Med Microbiol. 303(6):298-304

149. Aarestrup FM, Seyfarth AM, Emborg HD, Pedersen K, Hendriksen RS, Bager F (2001) Effect of abolishment of the use of antimicrobial agents for growth promotion on occurrence of antimicrobial resistance in fecal enterococci from food animals in Denmark. Antimicrob Agents Chemother. 45(7):2054-2059

150. Aarestrup FM (2000) Characterization of glycopeptide-resistant Enterococcus faecium (GRE) from broilers and pigs in Denmark: genetic evidence that persistence of GRE in pig herds is associated with coselection by resistance to macrolides. J Clin Microbiol. 38(7):2774-2777 
151. Chapman JS (2003) Disinfectant resistance mechanisms, crossresistance, and co-resistance. Int Biodeterior Biodegradation. 51(4):271-276

152. Farias LFP, Oliveira CJB, Medardus JJ, Molla BZ, Wolfe BA, Gebreyes WA (2015) Phenotypic and genotypic characterization of Salmonella enterica in captive wildlife and exotic animal species in Ohio, USA. Zoonoses Public Health. 62:438-444

153. Gast RK, Guraya R, Guard-Bouldin J, Holt PS, Moore RW (2007) Colonization of specific regions of the reproductive tract and deposition at different locations inside eggs laid by hens infected with Salmonella Enteritidis or Salmonella Heidelberg. Avian Dis. 51(1):40-44

154. Van Immerseel F, De Zutter L, Houf K, Pasmans F, Haesebrouck F, Ducatelle R (2009) Strategies to control Salmonella in the broiler production chain. Worlds Poult Sci J. 65(3):367-392

155. Roberfroid M (2007) Prebiotics: the concept revisited. J Nutr. 137(3):830S-837S

156. Schneitz C (2005) Competitive exclusion in poultry-30 years of research. Food Control. 16(8):657-667

157. Patterson JA, Burkholder KM (2003) Application of prebiotics and probiotics in poultry production. Poult Sci. 82(4):627-631

158. Andreatti Filho RL, Higgins JP, Higgins SE, Gaona G, Wolfenden AD, Tellez G, Hargis BM (2007) Ability of bacteriophages isolated from different sources to reduce Salmonella enterica serovar Enteritidis in vitro and in vivo. Poult Sci. 86(9):1904-1909

159. Lemos MPL, Saraiva MMS, Leite EL, Silva NMV, Vasconcelos PC, Giachetto PF, Freitas Neto OC, Givisiez PEN, Gebreyes WA, Oliveira CJB (2020) The posthatch prophylactic use of ceftiofur affects the cecal microbiota similarly to the dietary sanguinarine supplementation in broilers. Poult Sci. 99:6013-6021

160. Qian W, Yang M, Li X, Sun Z, Li Y, Wang X, Wang T (2020) Anti-microbial and anti-biofilm activities of combined chelerythrine-sanguinarine and mode of action against Candida albicans and Cryptococcus neoformans in vitro. Colloids Surf B: Biointerfaces 191:111003

161. Xue GD, Wu SB, Choct M, Pastor A, Steiner T, Swick RA (2017) Impact of a Macleaya cordata-derived alkaloid extract on necrotic enteritis in broilers. Poult Sci. 96:3581-3585

162. Hu NX, Chen M, Liu YS, Shi Q, Yang B, Zhang HC, Cheng P, Tang Q, Liu ZY, Zeng JG (2019) Pharmacokinetics of sanguinarine, chelerythrine, and their metabolites in broiler chickens following oral and intravenous administration. J Vet Pharmacol Therap. 42:197-206

163. Yadav S, Jha R (2019) Strategies to modulate the intestinal microbiota and their effects on nutrient utilization, performance, and health of poultry. J Animal Sci Biotechnol. 10:2

164. Bolder NM, Wagenaar JA, Putirulan FF, Veldman KT, Sommer M (1999) The effect of flavophospholipol (Flavomycin) and salinomycin sodium (Sacox) on the excretion of Clostridium perfringens, Salmonella Enteritidis, and Campylobacter jejuni in broilers after experimental infection. Poult Sci. 78(12):1681-1689

165. Andreoletti O, Budka H, Buncic S, Colin P, Collins JD, Koeijer A, Griffin J, Havelaar A, Hope J, Klein G, Kruse H, Magnino S, Antonio LM, McLauchlin J, Nguyen-The C, Noeckler K, Noerrung B, Maradona MP, Roberts T et al (2008) Microbiological risk assessment in feedingstuffs for food-producing animals Scientific Opinion of the Panel on Biological Hazards. EFSA. 720:1-84

166. EFSA Panel on Contaminants in the Food Chain (CONTAM) (2010) Scientific opinion on lead in food. EFSA. 8(4):1570

167. EFSA Panel on Biological Hazards (BIOHAZ) (2012) Scientific Opinion on the development of a risk ranking framework on biological hazards. EFSA. 10(6):2724

168. ECDC, EFSA Panel on Biological Hazards (BIOHAZ), \& EMA Committee for Medicinal Products for Veterinary Use (CVMP)
(2017) ECDC, EFSA and EMA Joint Scientific Opinion on a list of outcome indicators as regards surveillance of antimicrobial resistance and antimicrobial consumption in humans and foodproducing animals. EFSA. 15(10):e05017

169. FDA - U.S. Food and Drug Administration. Summary Minutes, Joint Meeting of the Veterinary Medicine Advisory Committee and Division of Anti-Infective Drugs Advisory Committee, Fluoroquinolones in Food Animal Medicine May11-12, 1994a. FDA Docket No. 00N-1571, Volume 61, DDI1, G-220

170. FDA - U.S. Food and Drug Administration. Transcript of the Joint Meeting of the Veterinary Medicine Advisory Committee and Anti-Infective Drugs Advisory Committee, May11-12, 1994b. FDA Docket No. 00N-1571, Volume 61, DDI1, G-219

171. FDA - U.S. Food and Drug Administration (2000) Enrofloxacin for poultry; opportunity for hearing, notice. Fed Regist 65:64954-64965

172. Karp BE, Tate H, Plumblee JR, Dessai U, Whichard JM, Thacker EL, Hale KR, Wilson W, Friedman CR, Griffin PM, McDermott PF (2017) National Antimicrobial Resistance Monitoring System: two decades of advancing public health through integrated surveillance of antimicrobial resistance. Foodborne Pathog Dis. 14(10):545-557

173. FDA - U.S. Food and Drug Administration. The National Antimicrobial Resistance Monitoring System (NARMS) Strategic Plan 2012-2016. 2012a. Available at: www.fda.gov/downloads/ AnimalVeterinary/SafetyHealth/AntimicrobialResistance/Natio nalAntimicrobialResistanceMonitoringSystem/UCM236283.pdf. Accessed on 5 Nov 2021

174. Brazil. Ministry of Health. National Action Plan for the Prevention and Control of Antimicrobial Resistance (PAN-BR). 2018a. Available in Portuguese at: https://portalarquivos2.saude.gov.br/ images/pdf/2018/dezembro/20/af-pan-br-17dez18-20x28-csa. pdf. Accessed on 5 Nov 2021

175. Brazil. Brazilian Ministry of Agriculture, Livestock and Food Supply. National Action Plan for the Prevention and Control of Antimicrobial Resistance in Livestock (2018b) Available in Portuguese at: https://www.gov.br/agricultura/pt-br/assuntos/insum os-agropecuarios/insumos-pecuarios/programas-especiais/resis tencia-antimicrobianos/pan-br-agro. Accessed on 5 Nov 2021

176. Cardoso, M (2019) Antimicrobial use, resistance and economic benefits and costs to livestock producers in Brazil. OECD Food, Agriculture and Fisheries Papers. 135:OECD Publishing

177. American Veterinary Medical Association (AVMA). Judicious therapeutic use of antimicrobials, 2001Available at: http://avma. org/scienact/jtua/jtua98.asp. Accessed on 5 Nov 2021

178. DANMAP (2013) Use of antimicrobial agents and occurrence of antimicrobial resistancein bacteria from food animals, food and humans in Denmark. 2014. Available at: https://www.danmap. org/reports/2013. Accessed on 5 Nov 2021

179. DANMAP (2012) Use of antimicrobial agents and occurrence of antimicrobial resistancein bacteria from food animals, food and humans in Denmark. 2013. Available at: https://www.danmap. org/reports/2012. Accessed on 5 Nov 2021

180. Casewell M, Friis C, Marco E, McMullin P, Phillips I (2003) The European ban on growth-promoting antibiotics and emerging consequences for human and animal health. J Antimicrob Chemother. 52:159-161

181. Turnidge J (2004) Antibiotic use in animals-prejudices, perceptions and realities. J Antimicrob Chemother. 53:26-27

182. Pfaller MA (2006) Flavophospholipol use in animals: positive implications for antimicrobial resistance based on its microbiologic properties. Diagn Microbiol Infect Dis. 56:115-121

183. Behravesh CB (2019) One Health: over a decade of progress on the road to sustainability. Rev Sci Tech. 38(1):21-50

184. King LJ, Anderson LR, Blackmore CG, Blackwell MJ, Lautner EA, Marcus LC, Meyer TE, Monath TP, Nave JE, Ohle J, 
Pappaioanou M, Sobota J, Stokes WS, Davis RM, Glasser JH, Mahr RK (2008) Executive summary of the AVMA one health initiative task force report. J Am Vet Med. 233(2):259-261

185. Schwabe CW (1964) Veterinary medicine and human health, vol 29, 1st edn. Williams \& Wilkins, Baltimore, p 516

186. WHO - World Health Organisation (2015) Global action plan on antimicrobial resistance

187. WHO - World Health Organisation (2017) WHO guidelines on use of medically important antimicrobials in food-producing animals

188. FAO - Food and Agriculture Organization of the Uined Nations The FAO action plan on antimicrobial resistance 2016-2020. Rome Available online at. Published online 2016
189. White A, Hughes JM (2019) Critical importance of a one health approach to antimicrobial resistance. Ecohealth. 16(3):404-409

Publisher's note Springer Nature remains neutral with regard to jurisdictional claims in published maps and institutional affiliations. 